\title{
Ksenia KAKAREKO
}

Uniwersytet im. Adama Mickiewicza, Poznań

\section{Karta Polaka - narzędzie politycznego wpływu czy tarcza w ręku Polonii?}

\footnotetext{
Usiston
} stawa o Karcie Polaka wpisuje się w pewien zauważalny w Europie Środkowo-Wschodniej proces mający na celu wsparcie i podtrzymywanie kontaktów poszczególnych państw z diasporą, z członkami przynależącymi do narodu dominującego w tych państwach, a mieszkającymi poza jego granicami ${ }^{1}$. W Konstytucji polskiej w treści art. 6 ust. 2 wyra-

1 W literaturze podkreśla się, że w unormowaniach konstytucyjnych rozmaitych państw Europy Środkowo-Wschodniej znalazły się postanowienia określane jako „klauzule narodowej odpowiedzialności”, w których ustrojodawcy deklarowali potrzebę troski o narodowe, kulturowe i językowe potrzeby tych przedstawicieli poszczególnych narodów dominujących w tych państwach, których los rzucił za granicę. Zob. I. Halász, Models od Kin Minority Protection on Central and Estern Europe, w: O. Ieda, Beyond Sovereignty: From Status Law to Transntional Citizenship?, Slavie Research Center, Hokaido University, Sapporo, „Slavic Euroasian Studies” 2006, nr 9, s. 6; cyt. za: J. Jagielski, D. Pudzianowska, Ustawa o Karcie Polaka. Komentarz, Warszawa 2008, s. 12 i n. Takie zobowiązania pojawiły się w Konstytucji Ukrainy, Chorwacji, Słowenii, Rumunii, a także ustawach zasadniczych Włoch, Austrii, Gracji. Efektem tych zapisów konstytucyjnych było pojawienie się w systemach prawnych poszczególnych państw, ustaw szczególnych regulujących status i przyznających uprawnienia osobom należącym do narodów dominujących w tych państwach. W ustawach tych znalazły się również postanowienia odnoszące się do sposobów wspierania wspólnot narodowych poza granicami kraju. W niektórych systemach przewidziano wydawanie specjalnych dokumentów poświadczających przynależność do określonych narodów, a mieszkających poza granicami narodowego państwa. Takie rozwiązanie przyjęto m.in. w ustawodawstwie węgierskim (Karta Etnicznego Węgra i Karta Rodziny Etnicznego Węgra), słowackim (Zaświadczenie o statusie Słowaka za granica), greckim (Dowód Tożsamości Etnicznego Greka), rosyjskim (Zaświadczenie potwierdzające status współrodaka za granica). Preferencyjne traktowanie przez państwa macierzyste osób, które przynależą do narodu tworzącego to państwo nie jest regulowane żadnym aktem prawa międzynarodowego ani żadnym dokumentem politycznym jakiejkolwiek organizacji międzynarodowej bądź międzyrządowej. W rezultacie regulacje takie są kwestią woli politycznej, ale nie można ich traktować jako obowiązek prawny jakiegokolwiek państwa. Uprawnienia, przywileje i preferencje ustanawiane na rzecz przedstawicieli poszczególnych narodów, którzy znaleźli się 
źnie przewidziano, że „Rzeczpospolita Polska udziela pomocy Polakom zamieszkałym za granicą w zachowaniu ich związków z narodowym dziedzictwem kulturalnym”. Treść normy zawartej w tym przepisie stała się podstawą koncepcji, których ucieleśnieniem jest ustawa z dnia 7 września 2007 r. o Karcie Polaka ${ }^{2}$. Pierwszy projekt ustawy o Karcie został sformułowany w Senacie w kwietniu 1999 r. ${ }^{3}$ W uzasadnieniu projektu senackiego wskazano, że potrzeba ustanowienia Karty Polaka ,wypływa z obowiązku państwa wobec rodaków, którzy żyją poza granicami Polski i stanowiąc około 1/3 Narodu Polskiego, także tworzą Polskę". W tekście uzasadnienia podkreślono, że projektowana ustawa po jej uchwaleniu sprawi, że Polacy przyjeżdżający do Macierzy będą traktowani ,jak Polacy, a nie

poza granicami państwa stworzonego przez ten naród, stanowiąc poza tymi granicami mniejszość, winny być, jak wynika z treści raportu o preferencyjnym traktowaniu mniejszości narodowych opracowanego przez Komisję Wenecką - realizowane zasadniczo na obszarze państwa ojczystego a nie na terytorium, w którym zamieszkuje określona mniejszość. Zob. Dokumenty Europejskiej Komisji na Rzecz Demokracji przez Prawo (zwanej Komisją Wenecka) utworzonej w 1990 r. jako organ konsultacyjny Rady Europy. Report on the Preferential Treatment of National Minorities by their Kin-States, przyjęty przez Komisję Wenecką na 48. posiedzeniu plenarnym, Wenecja 19-20 października 2001 r., s. 205, dostępny na stronie www.vinece.coe.int.

2 Dz. U. 2007, Nr 180, poz. 1280; zm. 2008, Nr 52, poz. 305; Nr 214, poz. 1348; $\mathrm{Nr} 216$, poz. 1367. Warto już w tym miejscu zauważyć, że jakkolwiek postanowienia Konstytucji mówią o Polakach mieszkających za granicą i nie czynią różnic między tymi, którzy znaleźli się na terenie byłego Związku Radzieckiego, a pozostałymi mieszkającymi w Europie zachodniej, na terenie obu Ameryk itd., to jednak w treści preambuły ustawy mowa o „wypełnieniu moralnego obowiązku wobec Polaków na Wschodzie". Niewątpliwie wzorem dla przyjętych w Polsce rozwiązań były w znaczącym stopniu regulacje znane $\mathrm{w}$ ustawodawstwie słowackim i węgierskim.

Zob. druk sejmowy Sejmu IV kadencji nr 1206 Projekt ustawy o Karcie Polaka i trybie stwierdzania przynależności do Narodu Polskiego osób narodowości polskiej lub pochodzenia polskiego. Projektowi temu towarzyszyły projekty ustaw o obywatelstwie polskim (druk sejmowy Sejmu IV kadencji nr 1222) oraz o repatriacji (druk sejmowy Sejmu IV kadencji nr 1204). Inicjatorami prac legislacyjnych byli senatorowie Akcji Wyborczej Solidarność, ale projekty były poparte także przez senatorów Sojuszu Lewicy Demokratycznej. Projektowane ustawy były próbą kompleksowego uregulowania stosunku państwa polskiego do Polaków, którzy z różnych przyczyn, najczęściej wbrew swej woli, znaleźli się poza granicami kraju. Jak wynika z uchwały Senatu z 22 kwietnia 1999 r., Senat na podstawie art. 118 ust. 1 Konstytucji, wniósł do Sejmu projekt ustawy o Karcie Polaka i trybie stwierdzania przynależności do Narodu Polskiego osób narodowości polskiej lub polskiego pochodzenia. Do reprezentowania stanowiska Senatu w dalszych pracach nad projektem upoważniono senator Janinę Sagatowską. 
cudzoziemcy". Karta miała być także alternatywą dla tych wszystkich rodaków, którzy pragną kontaktów z Polską, a nie będą mogli bądź nie będą chcieli skorzystać z prawa do obywatelstwa polskiego. Wskazano także w uzasadnieniu projekt, iż jego powstanie jest wynikiem zabiegów Europejskiej Rady Wspólnot Polonijnych. W preambule podkreślono, że celem Karty jest „stworzenie przywilejów ojczyźnianych oraz potwierdzenie przynależności do Narodu Polskiego" osób wskazanych w dalszej części preambuły ${ }^{4}$.

W projekcie ustawy określano, że uprawnionymi do uzyskania Karty Polaka są osoby, które: posiadały obywatelstwo Rzeczypospolitej Pol-

4 Warto zauważyć, że określony w treści preambuły krag osób, które mogłyby ubiegać się o Kartę, nie pokrywa się w całości z katalogiem osób uprawnionych w myśl art. 2 do otrzymania tej Karty. W preambule mowa o: byłych obywatelach Rzeczypospolitej oraz ich potomkach, tych, którzy nie opuszczali Polski, a na skutek sytuacji powstałej po wojnie 1939-1945 r. znaleźli się poza jej granicami i pozbawieni zostali obywatelstwa polskiego, wreszcie o tych, którzy poprzez pochodzenie i kontynuację tradycji narodowych na obczyźnie czują się Polakami. Natomiast w treści art. 2 projektu ustawy pisze się, że uprawnionymi do otrzymania Karty są osoby, które: „1. posiadały obywatelstwo Rzeczypospolitej Polskiej, lecz wskutek sytuacji po wojnie 1939-1945 r. znalazły się poza jej granicami i pozbawione zostały obywatelstwa polskiego, 2. będąc obywatelami Rzeczypospolitej Polskiej i zamieszkując jej terytorium wyemigrowały wskutek prześladowań politycznych, narodowościowych, religijnych lub z przyczyn ekonomicznych, 3. nie posiadając nigdy obywatelstwa polskiego wykażą, że swym pochodzeniem, działalnością, używaniem języka polskiego jako mowy potocznej i wychowaniem potomstwa zaznaczyły w sposób oczywisty przywiązanie do narodowości polskiej”. Porównując zakresy preambuły i art. 2 warto zauważyć, że w preambule mowa o byłych obywatelach Rzeczypospolitej, co odnosić można do obywateli Rzeczypospolitej szlacheckiej, a więc do znacznej części ludności Łotwy, Litwy, Estonii, Białorusi, Ukrainy i części Rosji, natomiast w art. 2 projektu mowa o obywatelach Rzeczypospolitej Polskiej, a więc państwa istniejącego w okresie międzywojennym. W treści art. 2 wymienia się emigrantów prześladowanych z przyczyn politycznych, narodowych i religijnych oraz tych, którzy opuścili Polskę z przyczyn ekonomicznych. Preambuła nie dotyczy w ogóle tych kategorii. Tymi, którzy opuścili Polskę wskutek prześladowań byli także obywatele Rzeczypospolitej Polskiej m.in. narodowości żydowskiej. Tekst art. 2 ust. 2 zdaje się nie dotyczyć jednak tych obywateli polskich narodowości żydowskiej, którzy zostali zmuszeni do emigracji po 1968 r. Nie byli oni bowiem w tym momencie obywatelami PRL. Bardzo rozszerzona została także w art. 2 projektu ustawy wymieniona w jej preambule kategoria tych, ,którzy poprzez pochodzenie i kontynuację tradycji narodowych na obczyźnie czują się Polakami”. W myśl art. 2 takie osoby mają wykazać swym pochodzeniem, działalnością, używaniem języka polskiego jako mowy potocznej i wychowaniem potomstwa w sposób oczywisty przywiązanie do narodowości polskiej. 
skiej, lecz wskutek sytuacji po wojnie 1939-1945 r. znalazły się poza jej granicami i pozbawione zostały obywatelstwa polskiego, będąc obywatelami Rzeczypospolitej Polskiej i zamieszkując jej terytorium wyemigrowały wskutek prześladowań politycznych, narodowościowych, religijnych lub z przyczyn ekonomicznych, nie posiadając nigdy obywatelstwa polskiego wykażą, że swym pochodzeniem, działalnością, używaniem języka polskiego jako mowy potocznej i wychowaniem potomstwa zaznaczyły w sposób oczywisty przywiązanie do narodowości polskiej ${ }^{5}$. Karta miała uprawniać jej posiadacza do: uzyskania wizy narodowościowej, nieograniczonego w czasie prawa pobytu na terenie Rzeczypospolitej Polskiej, wjazdu na terytorium Rzeczypospolitej Polskiej bez obowiązku posiadania środków niezbędnych do pokrycia kosztów wjazdu, przejazdu, pobytu i wyjazdu, obciążających cudzoziemców, dostępu do szkół publicznych wszystkich szczebli na zasadach obowiązujących obywateli polskich, świadczeń z zakresu opieki zdrowotnej w czasie pobytu na terytorium Rzeczypospolitej Polskiej na zasadach obowiązujących obywateli polskich, nauki języka polskiego $\mathrm{w}$ formach zorganizowanych i poznania literatury kraju pochodzenia, na zasadach ustalonych przez ministra właściwego do spraw nauki, otrzymywania orderów i odznaczeń przysługujących obywatelom polskim za zasługi i cnoty obywatelskie, wybitne osiagnięcia i zasługi cywilne i wojskowe położone w czasie pokoju lub wojny, dla chwały Rzeczypospolitej lub w służbie społeczeństwu, zwolnienia w czasie pobytu na terytorium Rzeczypospolitej z opłat i danin publicznych, obciążających cudzoziemców ${ }^{6}$. W projekcie stwierdzono, że Karta jest urzędowym dokumentem osobistym, którym władze Rzeczypospolitej Polskiej, w sposób formalny, potwierdzają polską narodowość lub pochodzenie posiadacza dokumentu ${ }^{7}$. W myśl projektu dokument miał być wydawany na czas nieokreślony. W celu uzyskania Karty ubiegający się o jej wydanie powinien przed konsulem Rzeczypospolitej Polskiej złożyć wniosek, poświadczoną urzędowo kopię ważnego dokumentu tożsamości, oświadczenie o polskiej narodowości lub pochodzeniu oraz dowody polskiego pochodzenia. W tekście projektu przewidziano wyjątki od wymogu potwierdzenia pochodzenia polskiego za pośrednictwem przewidzianych

5 Art. 1 Projektu ustawy o Karcie Polaka z 1999 r., dokument zamieszczony został na oficjalnej witrynie internetowej Senatu Rzeczpospolitej Polskiej, http://www.senat.gov.pl/K4/DOK/UCH/34/147UCH.HTM.

${ }^{6}$ Art. 3 Projektu ustawy o Karcie Polaka z 1999 r.

7 Art. 5 Projektu ustawy o Karcie Polaka z 1999 r. 
dokumentów. Stwierdzono, że łączność z Narodem Polskim może być dowodzona przynależnością do organizacji polskich lub udziałem „w walce o sprawę polską", względnie wynikać z postawy i języka, bądź z pielęgnowania $\mathrm{w}$ rodzinie polskich obyczajów, ze związku z polską kulturą i życiem Polaków, z postawy w okresie obcego panowania, dowodzącej solidaryzowania się z Polakami, z narażeniem się na osobiste niebezpieczeństwo $^{8}$. W przypadku braku jakichkolwiek dokumentów lub innych dowodów pośrednich - w myśl projektu - uznane miały być wnioski osób znających język polski, które okażą swym zachowaniem, że poczuwają się do polskości. Rozwiązanie to znacząco poszerzało krag osób, które mogły dowodzić swej przynależności do Narodu Polskiego. Warto zwrócić uwagę na przypadki, w których miała następować odmowa wydania Karty, a mianowicie: skazanie wnioskodawcy prawomocnym wyrokiem sądu za przestępstwo umyślne, chyba że udowodni że skazany został za działalność na rzecz Państwa Polskiego, stwierdzona prawomocnym wyrokiem działalność wnioskodawcy za granicą na szkodę Państwa Polskiego, w przypadku uzasadniającym na podstawie przepisu szczególnego odmowę przyznania obywatelstwa polskiego. Unieważnienie wydanej Karty zostało przewidziane jedynie w sytuacji podania informacji, które okazały się niezgodne z prawdą, a posłużyły za podstawę do wydania Karty.

Projekt sformułowany w 1999 r. zwany w literaturze ,projektem senackim” nie został uchwalony. Kolejny projekt powstał w wyniku poprawek zaproponowanych podczas prac nad projektem senackim podjętych przez Komisję Administracji i Spraw Wewnętrznych oraz Komisję Łączności z Polakami za Granicą (nosi on w doktrynie nazwę ,projektu senackiego z poprawkami”) ${ }^{9}$. Kolejny projekt był inicjatywą rządu i został sformułowany w 2006 r. w ramach prac Międzyresortowego Zespołu ds.

8 Rozwiązania te wydają się mało precyzyjne i w praktyce mogły podlegać różnorodnej interpretacji. Pozawalałyby one na ubieganie się o Kartę Polaka osobom nie mającym żadnych związków z polskością, które np. z przyczyn humanitarnych solidaryzowały się $\mathrm{z}$ Polakami w okresie gdy poddawani byli oni restrykcjom. Podobnie mało ostry wydaje się termin ,narażenia na osobiste niebezpieczeństwo”, w praktyce ustalenie realności takiego niebezpieczeństwa mogło być niezmiernie trudne do udowodnienia, poza tym działalność bądź postawa wspomnianych osób mogła narażać nie je na niebezpieczeństwo, ale osoby im bliskie, w tym nie tylko członków rodziny.

9 Projekt ten został sformułowany w druku sejmowym 2641 wraz ze sprawozdaniem o senackim projekcie Karty Polaka i trybie stwierdzania przynależności do Narodu Polskiego osób narodowości polskiej lub polskiego pochodzenia. 
Polonii i Polaków za Granicą. Związany był z tzw. pakietem ustaw polonijnych $^{10}$.

Projekt ustawy z 1999 r. od początku budzić musiał wiele zastrzeżeń i nie wszystkie $\mathrm{z}$ nich zostały zlikwidowane $\mathrm{w}$,,projekcie senackim z poprawkami” z 2001 r. i w obecnej ustawie. W preambule projektu z 2001 r. stwierdzono, że ustawa o Karcie Polaka ma na celu wzmocnienie więzi rodaków na obczyźnie z Ojczyzną, uznając że należy im się głęboki szacunek i zadośćuczynienie moralne za utratę obywatelstwa polskiego ${ }^{11}$. Tak więc treść preambuły odchodzi wyraźnie od tekstu zawartego w projekcie z 1999 r. - do którego w znaczącej mierze wróciła obecnie obowiązująca ustawa. Inaczej także określono krag osób, które mogą ubiegać się o Kartę Polaka stwierdzając, że należą do nich osoby pochodzenia polskiego, nie będące obywatelami Rzeczypospolitej Polskiej, zamieszkujące na stałe poza granicami Polski. Tak więc projekt z 2001 r. wyraźnie rozszerzał krąg tych osób i nie wiązał Karty Polaka jedynie z ludnością polską zamieszkującą na Wschodzie.

Nie można nie zwrócić uwagi na fakt, iż osoby, które miały być beneficjentami ustawy, nawet mając pochodzenie polskie, w wielu przypadkach nigdy nie miały obywatelstwa polskiego. Do ,projektu senackiego z poprawkami" wprowadzono definicje podstawowych terminów, takich jak konsul, ustawa o cudzoziemcach, wiza i zezwolenie na osiedlenie się. Warto zwrócić uwagę na wprowadzenie kryteriów określających „pochodzenie polskie”, które później zostanie zastąpione bardziej ostrożnym określeniem ,„przynależności do Narodu Polskiego”. Możliwość taką dawać miało posiadanie w przeszłości obywatelstwa polskiego przez osobę ubiegającą się o Kartę albo przez jednego z jej rodziców lub dziadków. Osoba deklarująca narodowość polską winna była udowodnić, że ona sama lub jedno z jej rodziców bądź dziadków w przeszłości deklarowała

10 Projekty ustaw opracowane przez Międzyresortowy Zespót ds. Polonii i Polaków za Granica pod kierunkiem Sekretarza Stanu KPRM Adama Lipińskiego, Warszawa, wrzesień 2006.

${ }_{11}$ Zob. w przedmiocie utraty obywatelstwa przez Polaków zamieszkałych na obszarach zagarniętych po 17 września 1939 r. przez b. ZSRR. T. Jasudowicz, Powrót do obywatelstwa polskiego odebranego przez Zwiazek Sowiecki w czasie lub w zwiazku z II wojnq światowa, w: Obywatelstwo w Europie Środkowo-Wschodniej. Materiaty z konferencji „Prawo do posiadania obywatelstwa w Europie Środkowo-Wschodniej”, Jabłonna 15-17 grudnia 1995 r., red. P. Bajda, Warszawa 1996, s. 95 i n.; W. Ramus, Instytucja prawa o obywatelstwie polskim, Warszawa 1980, s. 122 i n.; W. Czapliński, Obywatelstwo zagrabione, „Gazeta Wyborcza” z 26 listopada 1991 r., s. 12. 
narodowość polską, bądź manifestowała w inny sposób swój związek z polskością, ewentualnie że ona bądź jej wstępni (rodzice, dziadkowie) uznawani byli za osoby narodowości polskiej. Trzeba zauważyć, że w tej formie kragg osób, które mogłyby ubiegać się o zaliczenie do osób pochodzenia polskiego, jest bardzo obszerny, a jednocześnie kryteria wskazane w projekcie niezbyt jasne. Od razu pojawia się pytanie w jaki sposób należy udowodnić fakt manifestacji swojej polskości i przez kogo miałyby być uznawane te osoby za osoby pochodzenia polskiego. Pozwala to sądzić, że taki zapis prowadziłby albo do oddania kwestii uznania polskiego pochodzenia Polaków mieszkających poza granicami Ojczyzny w ręce konsulów, nie dając im szczegółowych wskazań w ustawie, co pozwalało by na podejmowanie dość woluntarystycznych decyzji albo wręcz przeciwnie w jego wyniku powstałaby sytuacja, w której udowodnienie swoich więzi z polskością byłoby jedynie formalnością i pochodzenie polskie mogłaby deklarować ogromna ilość osób faktycznie związana z polskością z różnych powodów, najczęściej ekonomicznych, a nie z racji odczuwania więzi z Narodem Polskim, jego kulturą i językiem. Trzeba zwrócić uwagę na fakt, że obowiązująca ustawa o repatriacji określa zasady uznania pochodzenia polskiego, które nie są zbieżne ze wskazanymi w tym projekcie ustawy. Mogło by to doprowadzić do sytuacji, gdy osoba, której pochodzenie polskie zostało uznane na podstawie ustawy o repatriacji będzie mogła ubiegać się o przyznanie jej Karty Polaka. Można pokusić się o stwierdzenie, że Karta Polaka była skierowana przede wszystkim do ludności polskiej zamieszkującej najbliższe państwa byłego Związku Radzieckiego, której nie dotyczyły w gruncie rzeczy regulacje ustawy o repatriacji ${ }^{12}$. W projekcie ustawy nie uregulowano $\mathrm{w}$ praktyce $\mathrm{w}$ ogóle

12 Już w preambule ustawy o repatriacji zaznacza się dość niespójnie, że uznając powinność Państwa Polskiego umożliwienia repatriacji Polakom, którzy pozostali na Wschodzie, a zwłaszcza w azjatyckiej części byłego Związku Socjalistycznych Republik Radzieckich, i na skutek deportacji, zesłań i innych prześladowań narodowościowych lub politycznych nie mogli w Polsce nigdy się osiedlić. Mówiąc o Polakach, którzy pozostali na Wschodzie zaznacza się dalej w ustawie, że wiza wjazdowa w celu repatriacji może być wydana osobie polskiego pochodzenia, która przed dniem wejścia w życie ustawy zamieszkiwała na stałe na terytorium obecnej Republiki Armenii, Republiki Azerbejdżańskiej, Republiki Gruzji, Republiki Kazachstanu, Republiki Kirgiskiej, Republiki Tadżykistanu, Republiki Turkmenistanu, Republiki Uzbekistanu albo azjatyckiej części Federacji Rosyjskiej. Z treści ustawy wynika, że nie obejmuje ona swoim zasięgiem mieszkańców Litwy, Łotwy, Estonii, Ukrainy, Białorusi i europejskiej części Rosji. 
procedury przyznawania Karty Polaka ograniczając się do stwierdzenia, że wydaje ją konsul. Jest to co najmniej zadziwiające, biorąc pod uwage wymogi znajomości języka oraz tradycji polskich, które powinno się określić w jakimś ogólnym dla wszystkich trybie, co pozwoliło by uniknąć uznaniowości w tej materii. Warto w tym miejscu przypomnieć, że w momencie prezentacji tego projektu już istniały standardy zdawania języka polskiego ,jako obcego” z uzyskaniem odpowiedniego certyfikatu potwierdzającego poziom jego znajomości. We wspomnianym projekcie przewidywano wydawanie Karty na czas nieokreślony.

Z treści projektu ustawy wynika, że głównym celem wydawanej Karty Polaka miało być umożliwienie osobom poczuwającym się do bycia Polakami nie tylko stworzenia warunków do wzmocnienia ich więzi z Ojczyzną, lecz także faktyczne upraszczenie ich osiedlania się na terenie Polski. Projekt dawał takim osobom możliwość edukacji na zasadach takich samych jak obywatele RP. Jednak obowiązująca ustawa o oświacie i tak uprawnia osoby nie będące obywatelami polskimi, a zamieszkujące na terenie państwa polskiego, do korzystania z nauki i opieki w przedszkolach, a podlegające obowiązkowi szkolnemu także do nauki i opieki w publicznych szkołach podstawowych, gimnazjach i publicznych szkołach artystycznych oraz publicznych placówkach na warunkach dotyczących obywateli polskich. Pojawiają się także wątpliwości, dotyczące stypendiów dla osób polskiego pochodzenia. W sytuacji gdy osoba będzie miała prawo podjęcia nauki na zasadach takich, jak obywatele Polski, osoby te powinny także posiadać prawo ubiegania się o pomoc materialną wypłacaną z budżetu na takich samych zasadach jak obywatele. W związku z tym dziwnym wydaje się stwierdzenie, że osoby te będą miały prawo ubiegania się o stypendia polonijne. Nie uwzględnia się także możliwości podjęcia pracy i prowadzenia działalności gospodarczej. Tak więc, sytuacja osób, które zdecydowały by się na osiedlenie w Polsce w innych sferach życia - poza edukacją - nie będzie się różniła niczym od sytuacji innych cudzoziemców. W ten sposób podkreślając w projekcie ustawy o Karcie Polaka uprzywilejowaną pozycję Polaków ze Wschodu, zachęcając do powrotu do etnicznej ojczyzny, Polska w praktyce nie gwarantuje im po osiedleniu się w jej granicach żadnej szczególniejszej opieki. Uprawnienia pojawiające się po uzyskaniu pozwolenia na osiedlenie się wynikają $\mathrm{z}$ faktu posiadania tego pozwolenia, a nie z racji polskiego pochodzenia.

Podstawy odmowy wydania Karty przewidziane w pierwszym z projektów przejęła obowiązująca ustawa. Znalazły się wśród nich: skazanie wnioskodawcy prawomocnym wyrokiem sądu za przestępstwo umyślne, 
chyba że udowodni że skazany został za działalność na rzecz Państwa Polskiego oraz stwierdzoną prawomocnym wyrokiem działalność wnioskodawcy za granicą na szkodę Państwa Polskiego. W tym miejscu trzeba zwrócić uwagę na fakt, że nie zostało określone o wyrok jakiego sądu chodzi w tym przypadku. Czy chodzi o wyrok polskiego sądu czy może o wyrok sądu kraju zamieszkania. W takim wypadku jak można mówić o działalności na szkodę Polski. O ile mowa o przestępstwie umyślnym, to pojawia się także obawa czy taki zapis nie będzie przejawem dyskryminacji osób polskiego pochodzenia ze względu na skazanie wyrokiem sądu. Rodzi to pytanie - czyżby na podstawie tego projektu ustawy można wnioskować, że Polska chce pamiętać o osobach polskiego pochodzenia, ale jedynie tych, którzy nie psują pozytywnego wzoru Polaka? Poza tym wydawałoby się, że posiadanie Karty Polaka powinno potwierdzać znajomość języka polskiego, kultury polskiej, pochodzenia polskiego i raczej nie powinno być oceniane poprzez czynniki nie związane $\mathrm{z}$ tą dziedziną.

Dalej w projekcie zawarte zostały regulacje określające funkcjonowanie rejestru wniosków osób ubiegających się o wydanie Karty, wniosków o stwierdzenie polskiego pochodzenia oraz Kart Polaka, które zostały unieważnione.

Projekt z 2001 r. (,,projekt senacki po poprawkach”) został skierowany w celu oceny do Biura Studiów i Ekspertyz Kancelarii Sejmu, które w swojej opinii w sprawie zgodności projektu z prawem Unii Europejskiej stwierdziło, że w obowiązującym prawie wspólnotowym nie istnieją żadne regulacje obejmujące zakres opiniowanego projektu ${ }^{13}$. Projekt został natomiast krytycznie oceniony przez rząd Jerzego Buzka ${ }^{14}$ i Sekretarza Komitetu Integracji Europejskiej Jacka Saryusza-Wolskiego. Komitet Integracji Europejskiej zauważył, że projekt nie uwzględnia wspólnotowego podziału wiz na krótkoterminowe i długoterminowe, co mogłoby utrudnić zakwalifikowanie polskich wiz do jednego z tych dwóch rodzajów. Projekt ten utrzymując podział na rodzaje wiz stał też w sprzeczności

13 Sprawozdanie Komisji Administracji $i$ Spraw Wewnętrznych oraz Komisji Łaczności z Polakami za Granicq o senackim projekcie ustawy o Karcie Polaka i trybie stwierdzania przynależności do Narodu Polskiego osób narodowości polskiej lub polskiego pochodzenia, druk sejmowy nr 2641, http://orka.sejm.gov.pl/Rejestrd.nsf/wgdruku/2641/\$file/2641.pdf.

14 Stanowisko Rzqdu wobec senackiego projektu ustawy o Karcie Polaka i trybie stwierdzania przynależności do Narodu Polskiego osób narodowości polskiej lub polskiego pochodzenia, druk sejmowy nr 1206-2641-x, http://orka.sejm.gov.pl/Rejestrd.nsf/8af70e7fca8ea6b3c125658e0038e26c/c0935edb35260cb5c1256a720033b0d 9/\$file/1206-2641-x.pdf. 
z projektem nowelizacji ustawy o cudzoziemcach, która je ujednolicała. KIE w swojej opinii postawił również tezę, że tworzenie uprzywilejowanej kategorii cudzoziemców - posiadaczy Kart Polaka - stanowi naruszenie zakazu dyskryminacji wyrażonego w Powszechnej Deklaracji Praw Człowieka, Międzynarodowym Pakcie Praw Gospodarczych, Społecznych i Kulturalnych, preambule Europejskiej Karty Socjalnej oraz Konwencji UNESCO w sprawie zwalczania Dyskryminacji w Dziedzinie Oświaty. Również Rada Ministrów w swojej opinii przedstawiła niedociagnnięcia projektu ustawy o Karcie Polaka. Projektowi zarzucono m.in. także brak spójności z prawem wspólnotowym (Rząd podzielił stanowisko Komitetu Integracji Europejskiej), sprzeczność z konstytucyjną i międzynarodową zasadą równego traktowania cudzoziemców, nieprecyzyjne oszacowanie kosztów oraz brak projektu przygotowania instytucji publicznych do obsługi Karty Polaka. W podsumowaniu rząd zaproponował uwzględnienie jego uwag $\mathrm{w}$ toku dalszych prac legislacyjnych oraz równoległe podjęcie innych działań zmierzających do poprawy sytuacji Polaków za granica. Do końca III kadencji Sejmu prac nad projektem nie ukończono.

Obecnie obowiązująca ustawa o Karcie Polaka została uchwalona 7 września 2007 r. ${ }^{15}$ Od stworzenia pierwotnych projektów minęło już ponad 5 lat i zmieniły się znacząco realia, w których trzeba było wprowadzać taki instrument jak Karta Polaka. W tym czasie Polska nie tylko została członkiem Unii Europejskiej, ale także weszła do strefy Schengen. Wymagało to wielu zmian i gruntownego dopracowania tekstu ustawy. Obecnie obowiązująca ustawa traktuje o wielu kwestiach bardziej ogólnikowo i ostrożnie. Wprowadzono także szereg nowych elementów i wiele spraw uszczegółowiono.

W preambule stwierdza się, że ustawa powstała w celu realizacji konstytucyjnego zapisu o pomocy Polakom zamieszkałym za granicą w zachowaniu ich związków z narodowym dziedzictwem kulturalnym. Nie wykreślono odwołania się do moralnego obowiązku wobec Polaków na Wschodzie, lecz nieco inaczej je sformułowano nie przywołując żadnych dat. Jako dopracowanie do poprzedniego odwołania się do wspomnianego

15 Ustawa o Karcie Polaka z dnia 7 września 2007 r., Dz. U. 2007, Nr 180, poz. 1280 z poźn. zm. Głosowanie nad przyjęciem projektu ustawy o Karcie Polaka odbyło się w Sejmie V kadencji w dniu 7 września 2007 r. na 47 posiedzeniu w 9 punkcie porządku dziennego. Za projektem głosowało 428 posłów, przeciw było 3 (wszyscy z SLD), żaden z posłów nie wstrzymał się od głosu. W głosowaniu nie wzięło udziału 29 posłów. 
moralnego obowiązku wyszło wspomnienie w preambule o osobach, które polskiego obywatelstwa nigdy nie miały, ale utożsamiają się z Narodem Polskim i pragną do niego należeć. Także zapisano jako cel ustawy wzmocnienie więzi łączących Polaków na Wschodzie z Macierzą oraz wspieranie ich starania o zachowanie języka polskiego oraz kultywowanie tradycji narodowej.

Główną zmianą różniącą obecną ustawę od poprzednich projektów jest odejście od stwierdzania pochodzenia polskiego, które pozostawia się ustawie o repatriacji oraz służbom konsularnym. Nie chcąc aby potwierdzenie polskości prowadziło Polaków posiadających obywatelstwo innych państw do utraty posiadanego przez nich obywatelstwa sformułowano bardzo ostrożne stwierdzenie o przynależności do Narodu Polskiego. $\mathrm{Z}$ jednej strony nie udało się uniknąć kolizji prawnej, a z drugiej strony nowe określenie pozwala nie tylko na wyróżnienie grupy obywateli polskiego pochodzenia, ale i na rozszerzenie katalogu posiadaczy Karty Polaka o osoby takowego pochodzenia nie posiadające, lecz odczuwające bliskość z Narodem Polskim, jego kulturą i językiem. Interesujące wydaje się sformułowanie Naród Polski także z uwagi na fakt, że terminem tym operuje w preambule Konstytucja z 1997 r., jednak z dodatkiem - wszyscy obywatele Rzeczypospolitej ${ }^{16}$. Jednak w nauce prawa konstytucyjnego

${ }^{16} \mathrm{~W}$ literaturze zwraca się uwagę na fakt, że pierwotnym dawcą demokratycznej ustawy zasadniczej jest tylko lud. Nigdy nie może nim być abstrakcyjna istota zwana narodem. Zob. Konstytucje Rzeczypospolitej oraz komentarz do Konstytucji RP z 1997 roku, red. J. Boć, Wrocław 1998, s. 9-10. Warto jednak pamiętać, że Naród Polski, jako prawodawcę wskazywała wcześniej preambuła Konstytucji marcowej. Podkreślić wypada, że w art. 6 Konstytucji z 1997 r. uczyniono znamienną dystynkcję między Polakami mieszkającymi w Rzeczypospolitej, a tymi, którzy zamieszkują za granica, stwierdzając, że tym ostatnim Rzeczypospolita Polska udziela pomocy w zachowaniu ich związków z narodowym dziedzictwem kulturalnym. Nie wspomniano przy tym, czy dotyczy ta pomoc jedynie Polaków posiadających obywatelstwo polskie czy też tych także, którzy je utracili. „Narodowe dziedzictwo kulturalne”, o jakim mowa w art. 6 ust. 2 Konstytucji to - jak zauważa się w doktrynie - pojęcie tożsame z określeniem „,dziedzictwo narodowe”, którym operuje art. 5 Ustawy Zasadniczej. „Związki z narodowym dziedzictwem kulturalnym" polegaja, jak zauważa P. Sarnecki na doznawaniu poczucia bliskości czy wręcz swoistej „własności” polskiej kultury materialnej i duchowej. Beneficjentami realizacji tej zasady polityki - jak zauważa ten autor - są wszyscy Polacy, bez względu na swój status w zakresie obywatelstwa, a więc zarówno obywatele RP (w tym Polacy o podwójnym obywatelstwie), jak i Polacy będącymi obywatelami innych państw, a także apatrydzi. Por. P. Sarnecki, Komentarz do art. 6 Konstytucji, w: Konstytucja Rzeczpospolitej Polskiej. Komentarz, red. L. Garlicki, t. V, Warszawa 2006, s. 2. 
odróżnia się Naród Polski w znaczeniu etnicznym, które zostało zawarte $\mathrm{w}$ ustawie $\mathrm{i}$ to pojęcie $\mathrm{w}$ znaczeniu prawnym, które właściwie zawarto w Konstytucji ${ }^{17}$. W ten sposób nie można traktować określenia Naród Pol-

${ }^{17}$ Według koncepcji naturalistycznej, naród traktowany jest jako grupa genetyczna, uwarunkowana właściwościami środowiska geograficznego, w jakim zamieszkiwała. W koncepcji politologicznej naród jest wspólnotą polityczną, tożsamą z państwem. Każde państwo zabiega o ukształtowanie w swoich ramach narodu. Zgodnie z koncepcją kulturową, naród jest ukształtowaną w toku rozwoju historycznego społecznością, której członkowie uczestniczą we wspólnej kulturze narodowej obejmującej język, obyczaje, sztukę i naukę, działalność gospodarcza, tradycje i inne formy aktywności. Zob. J. Wiatr, Naród i państwo. Socjologiczne problemy kwestii narodowej, Warszawa 1973, s. 189-207; por. także J. Sobczak, Podstawy wiedzy o państwie i prawie, Poznań 2002, s. 28-29; A. Kłoskowska, Teoretyczne spory na temat narodu a ujęcie kulturologiczne i indywidualizujace, „Przegląd Zachodni” 1994, nr 4(273), s. 1-8. W tym ujęciu naród jest wspólnotą kultury. Wspólnota ma formę nie tylko faktyczną, lecz także ideologiczna, gdyż w tworzeniu kultury członkowie narodu kierują się pewnymi ideałami narodowymi, wizją, ideologia, aspiracjami w zakresie różnych dziedzin kultury. Zob. S. Ossowski, Więź spoleczna i dziedzictwo krwi, w: Dzieła, t. 2, Warszawa 1966; tenże, Analiza socjologiczna pojęcia ojczyzny, w: Dzieta, t. 3, Warszawa 1967, s. 210 i n.; tenże, O ojczyźnie $i$ narodzie, Warszawa 1984. Uznając, że naród ukształtował się w płaszczyźnie kultury, podkreśla się, że jest on w przeciwieństwie do państwa zbiorowością społeczną o charakterze kulturowej wspólnoty. Według E. Gellnera i B. Andersona, naród jest konstrukcją ideologiczna, a jego powstanie ma na celu odnalezienie związków między samookreślającą się kulturowo grupą a państwem. Obaj badacze, mimo dzielących ich różnic, genezę współczesnych narodów wiążą z rozwojem uprzemysłowienia i homogenizacją kultury oraz z przemianami społecznymi i kulturowymi. W tym ujęciu naród nie jest synonimem społeczeństwa w tym także społeczeństwa obywatelskiego. zob. E. Gellner, Narody, Nacjonalizm, Warszawa 1991, s. 14-16 i 65; B. Anderson, Wspólnoty wyobrażone. Rozważania o źródtach i rozprzestrzenianiu się nacjonalizmu, Kraków-Warszawa 1997, s. 25 i n.; Z. Ziembiński, Socjologiczne pojmowanie narodu, „Sprawy Narodowościowe - Seria Nowa” 1995, t. IV, z. 2(7), s. 165-175. Warto jednak zauważyć, iż w nauce polskiej dość mocno ugruntowany jest pogląd o niezależności narodu od państwa, które nie jest niezbędnym czynnikiem jedności narodowej. F. Znaniecki, Wspótczesne narody, Warszawa 1990, s. 25 i n. oraz 122 i n.; koncepcję narodu F. Znanieckiego omawiają m.in.: J. Szacki, Naród w socjologii Znanieckiego, „Przegląd Polonijny” 1983, nr 4 oraz W. Markiewicz, Florian Znaniecki jako socjolog narodu, w: Florian Znaniecki i jego rola w socjologii, red. A. Kwilecki, Poznań 1975; J. Szacki, Znaniecki: dylemat determinizmu i twórczości, „Kultura i Społeczeństwo” 1989, nr 3, s. 13-21. Zauważa się także, iż naród jest synonimem społeczeństwa, w tym także społeczeństwa obywatelskiego, we wszystkich jego znaczeniach. Wielu badaczy posługuje się pojemną koncepcją narodu państwowego na określenie wczesnej formy zbiorowości nie zróżnicowanej jeszcze etnicznie, ale podporządkowanej jednemu państwu, którego administracyjna polityka prowadzi do stopniowego ujednolicenia kultury tej zbiorowości. J. Bardach, Od narodu poli- 
ski w znaczeniu prawnym ${ }^{18}$ i nie może ono zobowiązywać państwa do nadania obywatelstwa osobie posiadającej Kartę Polaka.

tycznego do narodu etnicznego, „Kultura i Społeczeństwo” 1993, nr 4, s. 3-16; tenże, O powstaniu nowoczesnego narodu litewskiego, w: tegoż, O dawnej i niedawnej Litwie, Poznań 1988, s. 247-256. Por. w tym przedmiocie stanowisko L. Greenfeld, $N a$ tionalism. Five Roads to Modernity, Cambridge-Harvard 1992, s. 3 i 13 oraz L. Greenfeld, D. Chirat, Nationalism and Aggression, „Theory and Society” 1994, nr 1 s. 82 i n. Zob. także E. Shils, Naród narodowość i nacjonalizm a społeczeństwo obywatelskie, „Sprawy Narodowościowe - Seria Nowa” 1996, t. V, z. 1(8), s. 9-30. Zwraca także uwagę stanowisko Ch. Tilly, który posługując się sformułowaniem „Naród kierowany przez państwo" podkreśla znaczenie czynników kulturowych w kształtowaniu narodu, por. Ch. Tilly, State and Nationalism in Europe 1492-1992, ,Theory and Society" 1994, nr 1, s. 133-140; także Ch. Tilly, Formowanie się państw narodowych w Europie Zachodniej, w: Władza i społeczeństwo, red. J. Szczupaczyński, t. 2: Antologia tekstów z zakresu socjologii polityki, Warszawa 1998, s. 20. Zob. ciekawe uwagi H. Kubiaka, Przyczynek do sporu o naturę i przyszłość narodu-państwa, w: Idee a urzadzanie świata społecznego. Księga jubileuszowa dla Jerzego Szackiego, pod red. E. Nowickiej, M. Chałubińskiego, Warszawa 1999, s. 211-222.

18 Pojęcie narodu państwowego oraz zbliżone do niego pojęcie narodu kierowanego przez państwo nie są równoznaczne z narodem obywatelskim i nie implikuje demokratycznego charakteru państwa. Określenie „naród obywatelski” wiąże się z koncepcją społeczeństwa obywatelskiego, sformułowaną przez T. Hobbesa oraz rozwiniętą przez G. W. Hegla udzielającego szerokich instytucjonalnych gwarancji systemowi stosunków ludzkich. Według koncepcji A. D. Smitha, istnieją dwa aspekty narodu: terytorialno-obywatelski i etniczno-genealogiczny, które występują w różnych proporcjach w konkretnych przypadkach oraz wywodzą się z odmiennych typów etnicznych wspólnot i procesów narodowotwórczych. Naród, zdaniem A. D. Smitha, jest konstrukcją złożoną z wzajemnie powiązanych komponentów etnicznych, kulturowych, terytorialnych, ekonomicznych i prawno-politycznych. Koncepcja terytorialno-obywatelska narodu zakłada, iż jest on kulturową i polityczno-prawną wspólnotą, posiadającą swoje historyczne terytorium, zakładającą prawną i polityczną równość wszystkich członków oraz posiadającą wspólną obywatelską ideologię, która dostarcza wzorców zachowań, kształtuje aspiracje i jest podkładem idei członków tej społeczności. W myśl koncepcji etniczno-genealogicznej naród ujmowany jest jako jedna wielka fikcyjna rodzina, w której dominuje endemiczna kultura, tradycja i język. Etniczny model określa członkostwo narodu, jako organicznie nieuniknione. Jednostka jest członkiem narodu bez względu na to, czy pozostaje we wspólnocie, czy też opuszcza ją na rzecz innej. Zob. A. D. Smith, National Identity, s. 14 i n. Podkreśla się, za Ferdinandem Tönniesem, że naród jest wspólnota, a nie społeczeństwem, gdyż dominują w jego łonie więzy pokrewieństwa, braterstwa i sąsiedztwa, przy czym głównym instrumentem kontroli społecznej jest zwyczaj i tradycja, a podstawą identyfikacji - świadomość zbiorowa. Zob. A. Przestalski, Lud, naród $i$ wola $w$ systemie socjologicznym Ferdinanda Tönniesa, „Sprawy Narodowościowe - Seria Nowa” 1995, t. IV, z. 1(6), s. 9-16. W przeciwieństwie do Tönnniesa Max Weber, także widzący w naro- 
Najważniejszym chyba punktem ustawy (wyjaśnienie dlaczego dalej) jest określenie wymogów, które powinna spełnić osoba starająca się o uzyskanie Karty Polaka. Pierwszym z nich jest wymóg wykazania swoich związków z polskością przez przynajmniej podstawową znajomość języka polskiego, który uważa za język ojczysty oraz znajomość i kultywowanie polskich tradycji i zwyczajów. Stwierdzenie to budzi bardzo dużo wątpliwości gdyż przyjmuje się, że sformułowanie ,język ojczysty” oznacza język, którego człowiek uczy się najpierw, którego przyswojenie na-

dzie wspólnotę, uważał, że jest to wspólnota wartości, z którą nierozłącznie wiąże się potrzeba odniesienia jednostki do postaw ustanawiających te wartości. W koncepcji Webera, naród występuje w kontekście wielkich struktur społecznych: państwa i społeczeństwa, ale nie jest z nimi utożsamiany. Według innych koncepcji, wyróżnić należy definicje rasowo-antropologiczne, psychologiczno-kulturowe, etatystyczne i wreszcie historyczne. Definicje rasowo-antropologiczne widzą w narodzie wspólnotę ,pochodzenia” bądź „krwi”; psychologiczno-kulturowe kładą nacisk na konieczność wytworzenia przez naród własnej kultury duchowej i materialnej oraz pojawienie się świadomości więzi narodowej i poczucia odrębności. W ujęciach etatystycznych akcentuje się związki między narodem a państwem, utożsamiając naród z obywatelami państwa i wskazując, że każdy naród dąży do stworzenia własnego państwa, aczkolwiek nie każdemu udaje się ten cel osiagnąć. Definicje historyczne pojmują naród jako złożony wytwór procesów historycznych. W Polsce wielu badaczy, w ślad za Jerzym Szackim, podkreśla, że w rozważaniach nad narodem pojawiają się dwa sposoby myślenia. Pierwszy z nich akcentuje fakt, że naród jest zbiorowością zamieszkująca wspólne terytorium i podlegającą tym samym prawom. Drugi podkreśla, że narodem jest przede wszystkim historycznie ukształtowana wspólnota kulturowa. J. Szacki, Koncepcja narodu w socjologii i historii, w: tegoż, Dylematy historiografii idei oraz inne szkice i studia, Warszawa 1991, s. 360, 351-363 (pierwodruk tekstu pt.: Koncepcja narodu w socjologii i historii: podobieństwa i różnice, „Przegląd Powszechny” 1986, nr 7, s. 182-193; tenże, Kłopoty z pojęciem narodu, w: Humanistyka przełomu wieków, red. J. Kozielecki, Warszawa 1999, s. 153-154 oraz to samo „Odra” 1999, s. 11-16. W klasycznej literaturze prawniczej, socjologicznej i politologicznej formułowane są definicje genetyczne i strukturalne narodu. W definicjach genetycznych określa się naród poprzez wskazanie czynników, które złożyły się na jego powstanie. W definicjach strukturalnych wskazuje się cechy, które „na ogół” charakteryzują grupę społeczną zwaną narodem. W zależności od tego, jakie cechy brane są pod uwagę przez definiującego, mówi się o definiowaniu narodu w kategoriach materialnych, politycznych, kulturowych oraz świadomościowych. Szczególnie interesujące wydają się te rozwiązania, które podejmują próby sformułowania definicji narodu poprzez wyliczenie elementów składających się na to pojęcie. Według G. Kellasa, naród tworzą czynniki o charakterze obiektywnym: terytorium, język, religia, wspólne pochodzenie, aczkolwiek nie wszystkie występują w odniesieniu do każdego narodu, oraz czynniki subiektywne: świadomość odrębności narodowej i demonstrowane przez ludzi przywiązanie do niej. 
stępuje w dzieciństwie, odbywa się w sposób naturalny, a ma miejsce w środowisku zajmującym się główną opieką nad małym człowiekiem, najczęściej jest to jego środowisko rodzinne ${ }^{19}$. W tym rozumieniu dziwnym wydaje się zestawienie wymogu uznania języka polskiego za język ojczysty i znajomość tego języka na poziomie przynajmniej podstawowym, gdyż oznacza to wymóg przynajmniej podstawowej umiejętności mówienie, czytania, rozumienia poleceń. Sama kwestia oceny poziomu znajomości języka, gdyż kryteria oceny nie zostały określone i rozwiązania dla tej sytuacji pozostawiono w gestii konsulów ${ }^{20}$. Kwestia znajomości polskich zwyczajów i tradycji oraz ich kultywowanie budzi nie mniej kontrowersji, gdyż pojawia się pytanie o jakie konkretnie polskie tradycje i zwyczaje miało by w tym przypadku chodzić i czy wszystkie te tradycje i zwyczaje, które od razu przychodzą na myśl są wyłącznie polskie. Nawet gdy przyjmiemy, że są to zwyczaje polskie, to czy możemy wyłączyć

19 Z. Klemensiewicz, O różnych odmianach współczesnej polszczyzny, w: Z. Klemensiewicz, W kręgu języka literackiego i artystycznego, Warszawa 1961, s. 108 i n; A. Furdał, Językoznawstwo otwarte, Opole 1977, s. 151. Wydaje się, że język ojczysty to język ogólnonarodowy zwany także czasami językiem ogólnym. Definiuje się go jako ogólną odmianę kulturalną języka narodowego, czyli tę odmianę, która jest rozpowszechniana przez szkołę, administrację, literaturę i prasę, a służyć ma jako środek porozumiewania się we wszystkich dziedzinach członków narodu. Zob. Encyklopedia języka polskiego, red. S. Urbańczyk, Wrocław-Warszawa-Kraków 1992, s. 135.

${ }^{20}$ W większości placówek dyplomatycznych nie obowiązują żadne konkretnie określone zasady. Wyjątkiem może służyć Konsulat Generalny RP w Odessie, który na swojej stronie internetowej zamieszcza dokument, który określa takie kryteria. Mowa w tym dokumencie o tym, że zgodnie z wymogami Rady Europy, dotyczącymi poświadczania znajomości języka, osoba znająca język polski na poziomie podstawowym: rozumie proste pisane informacje, właściwie reaguje na proste pytanie, prośbę, informację, prostymi zdaniami mówi o sobie, rodzinie, miejscach jej bliskich, o Polsce, zapisuje swoje dane osobowe. Zaznacza się także, iż na podstawie odpowiedzi na zadawane pytania konsul będzie mógł stwierdzić, czy wnioskodawca: rozumie sens zadanego pytania; rozumie sens prostego polecenia (prośby) typu: „Proszę powiedzieć”, „Proszę napisać”; rozumie znaczenie słów w kontekście (ogólny sens wypowiedzi). Podkreśla się również, że odpowiedzi na wybrane pytania (tematy) pozwolą konsulowi stwierdzić, czy ubiegający się o Kartę potrafi budować proste wypowiedzi dotyczące teraźniejszości, przeszłości, przyszłości, formułować krótką wypowiedź o sobie, swojej rodzinie, kraju zamieszkania i Polsce, formułować proste wypowiedzi, odnoszące się do przestrzeni (wnioskodawca pyta o drogę, udziela odpowiedzi dotyczącej drogi do konkretnego punktu), czasu (pyta o godzinę, odpowiada na pytanie: „Która godzina”), rozpoczynać, prowadzić i kończyć rozmowę. Zob. Witrynę internetową Konsulatu Generalnego RP w Odessie, http://www.odessakg.polemb.net/index.php?document $=79$. 
jedną wspólną formę, która uwzględniałaby różnorodność regionalną Polski? Czy osoba wychowana w Polsce np. w kulturze i tradycjach Podlasia faktycznie posiadacza wystarczającą wiedzę o tradycjach Wielkopol$\mathrm{ski}^{21}$ ? Warto także zastanowić na ile polskie tradycje i zwyczaje są związane, a nawet zdeterminowane przez wyznanie rzymsko-katolickie. W tej sytuacji pojawia się możliwość dyskryminacji osób wedle wyznania, gdyż osoby, które nie podpadają pod stereotyp Polaka-katolika mogą mieć mniejsze szanse pozytywnego spełnienia danego wymogu. Czyli można dojść do wniosku, że wyznawcy innej wiary są mniej wartościowi dla Polski. Jednak większe kontrowersje budzi fakt, że ocenę takiego związku z polskością wystawia konsul. W sytuacji, gdy nie ma ustalonych konkretnych kryteriów oceny kwestia ta ma bardzo duży poziom uznaniowości. Może to prowadzić do nadużyć, albo sytuacji, kiedy zostanie wydana Karta, czyli uznany za wystarczający zostanie poziom znajomości języka nie pozwalający na bezproblemowe funkcjonowanie w Polsce posiadacza tej karty, a przede wszystkim w świetle uprawnień, które Karta daje (o nich będzie mowa dalej).

Kwestia pisemnej deklaracji przynależności do Narodu Polskiego jest niejednoznaczna i może budzić wątpliwości ze strony władz państw byłego ZSRR odnośnie zamiarów strony polskiej, ponieważ nie zostało dokładnie zdefiniowane pojęcie Narodu Polskiego. W związku z tym, w sytuacji, gdy przyjmuje się, że Naród Polski ma znaczenie wyłącznie etniczne, Karta stwierdza narodowość polską posiadacza lub też przynależność do polskiej mniejszości. Z tego mogą wynikać zarzuty dwóch rodzajów - albo jest to wymóg pisemnej deklaracji swojej narodowości, co w wielu państwach byłego ZSRR jest zakazane na poziomie Konstytucji lub odpowiedniej ustawy, albo może zostać uznane takie działanie za próbę kształtowania mniejszości polskiej według kryteriów, które nie koniecznie są zgodne z kryteriami państwa, którego obywatelem jest posiadacz Karty. W tej sytuacji człowiek może posiadać Kartę Polaka, lecz nie przynależeć do mniejszości polskiej w oczach władz państwowych, lub odwrotnie - nie posiadając Karty być Polakiem w tym państwie. Takie działanie Polski może być odbierane jako mieszanie się do wewnętrznej

21 Polskie organizacje przyznające dofinansowanie dla kulturalno-oświatowych organizacji polonijnych na Wschodzie stawiają wymóg nauczania w szkołach polskich kultury różnych regionów, żeby pozostając w kręgu swojej regionalnej odmiany polskiej tradycji nie zatarły się więzi z Polską i jej kulturą w rozumieniu ogólnym i obejmującym kulturę całego Narodu Polskiego. 
polityki narodowościowej, a nawet podżeganie konfliktów na tym tle (jeżeli kryteria różnią się w wystarczająco znaczącym stopniu).

Kolejnym wymogiem jest wykazanie, że osoba ubiegająca się o Kartę jest narodowości polskiej lub posiada obywatelstwo polskie, lub co najmniej jedno z jej rodziców lub dziadków albo dwoje pradziadków było narodowości polskiej lub posiadało obywatelstwo polskie, albo przedstawi zaświadczenie organizacji polskiej lub polonijnej działającej na terenie tego państwa potwierdzające aktywne zaangażowanie w działalność na rzecz języka i kultury polskiej lub polskiej mniejszości narodowej przez okres co najmniej ostatnich trzech lat. To jest chyba jedno z bardziej kontrowersyjnych zdań ustawy. Rozwiązanie przyjęte przez ustawę jest bardzo zbliżone do brzemienia art. 5 ust. 1 ustawy o repatriacji ${ }^{22}$. Główna różnica polega na wprowadzaniu możliwości posiadania obywatelstwa polskiego w przeszłości oraz możliwości poświadczenia przez organizację polską lub polonijną więzi z polskością poprzez aktywną działalność w tej sferze. Wątpliwości budzi fakt wpisania uprawnień wspomnianych organizacji. Pojawia się pytanie czy zaświadczenie wydane przez nie będzie w pełni zastępowało dokumenty potwierdzające polskie pochodzenie. Zastanawiać może wykaz organizacji, które mają prawo wydawania odpowiednich zaświadczeń, gdyż np. na Białorusi Związek Polaków pod kierownictwem A. Borys nie jest jedyną organizacją polonijną mającą długą historię i spory zasięg. Ponadto fakt, że wskazany w wykazie Związek nie jest uznawany przez oficjalne władze, nadaje całej procedurze politycznego odcienia, wręcz można się pokusić, że może zostać potraktowany jako manifestacja opozycyjnego nastawienia do władz państwowych tak ze strony Polski, jak i ze strony osób ubiegających się o takowe zaświadczenie. Ponadto pojawia się kwestia tego, że organizacje polonijne w dużej mierze podejmują decyzję o przynależności do Narodu Polskiego biorąc na siebie kompetencje polskich i białoruskich organów państwowych. Jest to dziwne w perspektywie wszystkich możliwości, które daje państwo polskie opłacając je z pieniędzy podatników polskich, tym samym organizacje polskie w państwach na Wschodzie mają prawo same decydować, kto będzie mógł z tych udogodnień korzystać nawet nie mając pochodzenia polskiego.

22 Ustwa z dnia 9 listopada 2000 r. o repatriacji tekst jedn. Dz. U. 2004, Nr 53, poz. 532 . 
W art. 2 ust. 2 ustawy formułuje się kolejny wymóg stawiany osobom ubiegającym się o Kartę Polska, stwierdzając, że może być ona przyznana wyłącznie osobie posiadającej w dniu złożenia wniosku obywatelstwo jednego z państw byłego ZSRR albo posiadającej w jednym $\mathrm{z}$ tych państw status bezpaństwowca. Wynika z tego zapisu, że z Karty nie mogą skorzystać Polacy zamieszkujący w innych państwach. Co może stwarzać problem nierównego traktowania obywateli UE, biorąc pod uwagę fakt, że Litwa, Łotwa u Estonia wchodzą razem z Polską w skład UE ${ }^{23}$. Początkowo Urząd Komitetu Integracji Europejskiej ocenił takie rozwiązanie, jako niezgodne z prawem Unii Europejskiej, gdyż zakłada nierówne traktowa-

23 Pojęcie „obywatelstwa” wchodzi w skład siatek pojęciowych różnych dyscyplin z zakresu nauk społecznych. Posługują się nim zarówno prawnicy: konstytucjonaliści, administratywiści, teoretycy państwa i prawa, filozofowie prawa, jak i politolodzy, socjolodzy oraz historycy. Ten stan rzeczy powoduje pewne zamieszanie terminologiczne, będące zarzewiem sporów i nieporozumień. Generalnie, nie neguje się jednak, iż obywatelstwo stanowi instytucję prawną osadzoną w prawie konstytucyjnym, międzynarodowym i administracyjnym, głęboko powiązaną nie tylko z państwem, lecz także ze społeczeństwem, mającą swój wymiar psychologiczny i socjologiczny. W literaturze zwykle podkreśla się, że obywatelstwo to trwały lub względnie trwały, zarówno w aspekcie czasowym, jak i przestrzennym, węzeł prawny łączący jednostkę (osobę fizyczną) z państwem. Zob. J. Jagielski, Obywatelstwo polskie: zagadnienia podstawowe, Warszawa 1998, s. 16-17; M. Wyrzykowski, Obywatel i biurokracja, w: Prawa człowieka w społeczeństwie obywatelskim, Warszawa 1993, s. 52; M. Magoska, Obywatel w procesie zmian, Kraków 2001, s. 38 i n.; M. Smoktunowicz, Status administracyjno-prawny obywatela, w: System prawa administracyjnego, t. IV, Wrocław 1980, s. 7 i n.; Wielka encyklopedia prawa, red. E. Smoktunowicz, Białystok-Warszawa 2000, s. 541. Obywatelstwo w znaczeniu cywilnym to prawa obywatelskie (civil rights), a w zasadzie wolności obywatelskie, właściwe i przynależne wszystkim osobom fizycznym wchodzącym w skład określonego społeczeństwa, pojmowanego jako wielka grupa społeczna tworząca państwo, zaskarżalne przed sądem i niepodlegające arbitralnej odmowie ze strony państwa ani jakichkolwiek innych podmiotów. Prawa obywatelskie mogą jednak, jak podkreśla się w doktrynie, ulegać ograniczeniu z uwagi na potrzebę ochrony bądź praw innych jednostek, bądź ze względu na dobro powszechne. Obywatelstwo w znaczeniu politycznym pojmowane jest jako możliwość uczestniczenia w sprawowaniu władzy politycznej, zarówno w znaczeniu biernym, jak i czynnym. Wymiar społeczny obywatelstwa to gwarancje socjalne, prawo do odpowiedniego poziomu życia, ochrony zdrowia, możliwości kształcenia się, korzystania ze świadczeń społecznych, dorobku kulturalnego. W doktrynie konstatuje się stałe rozszerzanie zakresu pojęcia „obywatelstwo”, będące efektem modernizacji społeczeństwa, różnicowania strukturalnego, czego efektem jest powstawanie nowych instytucji i przekształcanie się dotychczasowych prostych struktur społecznych w złożone. 
nie obywateli $\mathrm{UE}^{24}$. Wynika to z tego, że osoby zamieszkujące w innych państwach Unii Europejskiej, nawet w przypadku spełnienia wszystkich

24 Opinia o zgodności z prawem Unii Europejskiej do sprawozdania Komisji Łaczności z Polakami za Granicq o rzqdowym projekcie ustawy Karta Polaka (druk $n r$ 1957) wyrażona na podstawie art. 2 ust. 1 pkt 2 z dnia 8 sierpnia 1996 r. o Komitecie Integracji Europejskiej (Dz. U. Nr 106 poz. 494, z późn. zm.) oraz w związku z art. 42 ust. 4 Regulaminu Sejmu przez Sekretarza Komitetu Integracji Europejskiej Tomasza Nowakowskiego, działającego z upoważnienia Przewodniczącego Komitetu Integracji Europejskiej, Urząd Komitetu Integracji Europejskiej, Min. TN 2177/07/DP/bwb, 31.08.2007. Idea obywatelstwa europejskiego kształtowała się dość powoli na marginesie polityczno-filozoficzno-prawnych koncepcji integracji europejskiej, których nie sposób w tym miejscu analizować. Jednolity Akt Europejski, podpisany w lutym 1986 r. nie rozwiązał kwestii obywatelstwa europejskiego. Obywatele państw członkowskich mieli być jedynie w pozostałych państwach Unii traktowani jako „uprzywilejowani obcokrajowcy". Na problem obywatelstwa europejskiego, począwszy od tej daty, zwracały uwagę liczne dokumenty polityczne, m.in.: memorandum belgijskie z marca 1990 r., raporty Martina z 14 marca 1990 r., 11 lipca 1990 r., memorandum hiszpańskie z 24 września 1990 r., opinia Komisji Europejskiej z 21 października 1990 r. Problem obywatelstwa europejskiego został w końcu uregulowany w Traktacie o Unii Europejskiej z 7 lutego 1992 r. (Traktat z Maastricht). W preambule tego dokumentu stwierdzono m.in., że wolą stron było ,ustanowienie obywatelstwa wspólnego dla obywateli swych krajów". Rozwinięcie treści deklarowanych w preambule następuje $\mathrm{w}$ art. B (obecnie art. 2, zgodnie z tabelą ekwiwalencyjną i treścią art. 12 Traktatu Amsterdamskiego), w którym stwierdzono m.in., iż Unia stawia sobie jako jeden z celów umacnianie ochrony praw i interesów obywateli Państw Członkowskich poprzez ustanowienie obywatelstwa Unii'. Tekst Traktatu z Maastricht podano w brzmieniu opublikowanym w Dzienniku Ustaw Dz. U. 2004, Nr 90, poz. 864/30. Jednocześnie, treścią wspomnianego traktatu o Unii Europejskiej (Traktatu z Maastricht) zawarto postanowienia zmieniające Traktat Ustanawiajacy Europejska Wspólnotę Gospodarcza w celu ustanowienia Wspólnoty Europejskiej. W treści Traktatu Ustanawiajacego Europejska Wspólnotę Gospodarczq dodano Traktatem z Maastricht art. 8 ust. 1 (obecnie art. 17), w którym stwierdzono, iż ,ustanawia się obywatelstwo Unii, a obywatelem Unii jest każda osoba mająca przynależność państwa członkowskiego". W ten sposób wprowadzono zależność prawną między Unią a jej obywatelami, łącząc jednocześnie obywatelstwo z dokumentem ustanawiającym Wspólnotę Europejską. Niezwykle interesującą treść wprowadzono do art. 8 ust. 1 (obecnie art. 17) w Traktacie Amsterdamskim uzupełniając treść tego ustępu zdaniem „Obywatelstwo Unii nie zastępuje obywatelstwa państwa, ale je uzupełnia” (Dz. U. 2004, Nr 90, poz. 864/31). Tym samym nie może budzić wątpliwości, że obywatelstwo Unii ma charakter subsydiarny i nie jest podobne do przynależności państwowej (obywatelstwa państwa jakiegoś kraju). Jednak związane są z nim i prawa, i obowiązki jednostki w ramach systemu Unii Europejskiej. Więź między jednostką a Unią nie ma jednak charakteru bezpośredniego, lecz wynika z obywatelstwa państwowego jednostki. Niektórzy badacze podkreślają, że więź ta nie ma charakteru formalnego, jak obywatelstwo państwowe, ale 
wymogów, nie będą mogły otrzymać Karty, mimo iż niewątpliwie należą do polskich mniejszości narodowych w tych państwach. Problem ten strona rządowa wyjaśniła argumentując, że ustawa ma przede wszystkim dotyczyć Polaków na Wschodzie ze względu na ogrom krzywd, których doznali, oraz z uwagi na to, że byli obiektem licznych działań mających na

symboliczny, chociaż charakteryzuje się także określoną zawartością materialną poprzez katalog praw. A. Wyrozumska, Jednostka w Unii Europejskiej, w: Prawo Unii Europejskiej, red. J. Barcz, Warszawa 2004, s. 378-379. W literaturze podnosi się, że wątpliwości musi wywoływać próba zdefiniowania związków między obywatelem a Unią, w sytuacji gdy ta ostatnia nie ma osobowości prawnej. Zauważa się także, że obywatelstwo Unii oparte zostało na więzi pozornej, co oznacza, że uzależnienie obywatelstwa europejskiego od przynależności państwowej jest automatyczne i bezwarunkowe. Jest to nie tyle więź wtórna, co więź pozorna, gdyż związek osoby fizycznej $z$ terytorium Unii jest pozorny, zważywszy, iż Unia nie jest suwerennym terytorium, lecz przestrzenią obowiązywania Traktatu. Por. J. Glaster, Z. Witkowski, Kompendium wiedzy o Unii Europejskiej, Torun 1996, s. 128; M. Zdanowicz, Obywatelstwo Unii Europejskiej, w: Integracja europejska. Wprowadzenie, red. M. Perkowski, Warszawa 2002, s. 355-356. Zauważa się także, że w odniesieniu do obywatelstwa Unii Europejskiej niższy poziom - narodowy - jest pierwotny w stosunku do europejskiego. Nieuprawniona byłaby więc teza, że obywatelstwo unijne przypomina federalne. Traktat z Maastricht, szczegółowo wyliczając prawa przyznane obywatelom Unii na plan pierwszy wysuwa prawo do swobodnego poruszania się i pobytu, stwierdzając, że obywatele Unii mają możność przemieszczania się i przebywania na terenie państw członkowskich z zastrzeżeniem warunków przewidzianych w Traktacie i postanowieniach przyjętych w celu jego wykonania. Zawarowano przy tym, że Rada może wydać przepisy ułatwiające wykonywanie praw pozwalających na swobodne przemieszczanie się obywateli Unii, stwierdzając, że winno to nastąpić jednomyślnie na wniosek Komisji i po uzyskaniu zgody Parlamentu Europejskiego (art. 8a ust. 1-2, obecnie w myśl tabeli ekwiwalencyjnej, art. 18). Prawo swobodnego poruszania się i pobytu znalazło swój wyraz jeszcze przed wejściem w życie Traktatu z Maastricht, z tym że dotyczyło ono obywateli państw członkowskich. Odnosiło się ono do jednostek aktywnych gospodarczo: pracowników najemnych, osób samodzielnie prowadzących działalność gospodarczą, w tym usługodawców. Z czasem prawa te rozszerzano na członków rodzin podmiotów uprawnionych, w końcu na odbiorców usług. Prawo swobodnego poruszania się i pobytu obejmuje uprawnienia umożliwiające wyjazd z państwa ojczystego bądź z innego państwa członkowskiego, wjazd na teren państwa członkowskiego, prawo przebywania na tym terytorium przejściowo przez dowolny czas oraz możliwość zamieszkania na stałe, wreszcie prawo do swobodnego przemieszczania się w granicach wybranego państwa. Zob. A. Wyrozumska, Jednostka, s. 381, tamże analiza aktów prawa wtórnego Unii i orzecznictwa dotyczącego tej kwestii oraz orzecznictwa Europejskiego Trybunału Sprawiedliwości. Por. także A. Cieleń, A. Szymański, Obywatelstwo, s. 53-54; L. Mitruś, Swoboda przemieszczania się pracowników. Komentarz, Kraków 2001. 
celu ich wynarodowienie. Skutkowało to uznaniem ustawy za zgodną z prawem unijnym ${ }^{25}$. Zaakceptował takie uzasadnienie także Senat na 47. posiedzeniu ${ }^{26}$.

Regulacja zawarta w art. 5 ust. 1, zatwierdzająca możliwość ubiegania się o zwolnienie z opłaty za przyjęcie i rozpatrzenie wniosku o wydanie wizy krajowej w celu korzystania $\mathrm{z}$ uprawnień wynikających z posiadania Karty Polaka lub refundację tej opłaty, rozwiązuje wątpliwości pojawiające się na gruncie możliwości zwolnienia z opłat Polaków zamieszkujących poza granicami Polski, nie łamiąc jednocześnie ustaleń Schengen, do której to strefy regulacji granicznych przystąpiła Polska pod koniec 2007 roku. Nie jest to bowiem ogólną zasadą udostępniania bezpłatnych wiz dla wszystkich posiadaczy Karty Polaka, a co za tym idzie i do całej Europy, a jednocześnie podkreśla się możliwość uzyskania takiej wizy.

Uprawnienia, które uzyskuje posiadacz Karty Polaka zostały zawarte $\mathrm{w}$ art. 6. Główne z nich zawarto w art. 6 ust. 1. Wraz z tymi uprawnieniami wiąże się zmiana szeregu ustaw. Tak zakłada się zwolnienie z obowiązku posiadania zezwolenia na pracę na zasadach określonych w ustawie $\mathrm{z}$ dnia 20 kwietnia 2004 r. o promocji zatrudnienia i instytucjach rynku pracy ${ }^{27}$. Wracając do kwestii możliwości uzyskania Karty Polaka nie posiadając pochodzenia polskiego, a jedynie posiadając zaświadczenie organizacji ludności polskiej potwierdzające aktywny udział w życiu społeczności polonijnej, można tu dopatrywać się możliwości pojawienia się korupcji, gdyż faktycznie pozwolenie na pracę w Polsce zależy w znaczącej mierze od opinii organizacji ludności polskiej za granicą. To samo można zakładać także w przypadku art. 6 ust. 1 pkt 2, pkt 3 oraz pkt 4, gdyż mowa w nich o podejmowaniu i wykonywaniu działalności gospodarczej na takich samych zasadach jak obywatele polscy ${ }^{28}$, o możliwości podejmowania

25 Opinia o zgodności z prawem Unii Europejskiej dodatkowego sprawozdania Komisji Łaczności z Polakami za Granicq o rzadowym projekcie ustawy Karta Polaka (druk nr 1957) wyrażona na podstawie art. 2 ust. 1 pkt 2 ustawy z dnia 8 sierpnia 1996 r. o Komitecie Integracji Europejskiej (Dz. U. Nr 106, poz. 494, z późn. zm.) przez Sekretarza Komitetu Integracji Europejskiej Tomasza Nowakowskiego, działającego z upoważnienia Przewodniczącego Komitetu Integracji Europejskiej, Urząd Komitetu Integracji Europejskiej, Min. TN 2249/07/DP/ik, 06.09.2007.

${ }_{26}$ Diariusz Senatu, nr 46, VI kadencja, www.senat.pl/k6/dok/diar/46/3.htm.

27 Dz. U. 2004, Nr 99, poz. 1001, z późn. zm.

28 Ustawa zakłada, że odbywać się to może na zadach określonych w ustawie z dnia 2 lipca 2004 r. o swobodzie działalności gospodarczej, Dz. U. 2007, Nr 155, poz. 1095. 
i odbywania studiów, studiów doktoranckich oraz innych form kształcenia, a także uczestnictwa $\mathrm{w}$ badaniach naukowych i pracach rozwojowych $^{29}$ oraz korzystania $\mathrm{z}$ form kształcenia na zasadach określonych w ustawie o systemie oświaty ${ }^{30}$. Pokazuje to nierówne traktowanie obywateli innych państw, zwłaszcza biorąc pod uwagę fakt, że Kartę Polaka może uzyskać nie tylko osoba deklarująca pochodzenie polskie. I tu znów można upatrywać nadzielenie znaczącymi możliwościami, uprawnieniami oraz zadaniami, które w odniesieniu do pozostałych cudzoziemców należą do urzędników rozmaitych urzędów i organizacji, nie zapominając o uprawnieniach do decydowania o wydatkach finansowanych z budżetu Polski. Jest nadzwyczaj kontrowersyjne zwłaszcza w przypadku Związku Polaków na Białorusi, która to organizacja jest jedyną uprawnioną do wydawania stosownych zaświadczeń, mimo że ta organizacja działa bez państwowej rejestracji, co jest sprzeczne z Kodeksem Karnym Białorusi ${ }^{31}$. Poza tym możliwość dana przez ustawodawcę posiadaczowi Karty Polaka do podejmowania nauki na różnych poziomach na zasadach obowiązujących obywateli polskich może rodzić spore problemy. Przed wprowadzeniem w życie ustawy o Karcie Polaka, osoby polskiego pochodzenia mogły się dostać na studia do Polski po zdaniu egzaminów przed komisją

29 Ustawa zakłada, że odbywać się to może na zasadach określonych w ustawie z dnia 27 lipca 2005 r. - Prawo o szkolnictwie wyższym, Dz. U. 2005, Nr 164, poz. 1365 , z późn. zm.

30 Ustawa z dnia 7 września 1991 o systemie oświaty, Dz. U. 2004, Nr 256, poz. 2572, z późn. zm.

31 Art. $193^{1}$ Kodeksu Karnego Białorusi zakłada, że organizacja działalności lub udział w działalności partii politycznej, innej organizacji społecznej, organizacji religijnej lub fundacji, w stosunku do której została wydana prawomocna decyzja uprawnionych organów państwowych o ich likwidacji albo zawieszeniu ich działalności, jak również organizowanie działalności lub udział w działalności partii politycznej, innej organizacji społecznej, organizacji religijnej lub fundacji, która nie przeszła rejestracji państwowej określonej przez odpowiednią ustawę karane jest grzywną lub aresztem do sześciu miesięcy lub pozbawieniem wolności do lat dwóch. Art. $193^{1}$ pojmuje pod działalnością partii politycznej, innej organizacji społecznej, organizacji religijnej lub fundacji działania skierowane na osiagnięcie celów wskazanych m.in. w statucie lub innych dokumentach tych organizacji. Podkreśla się także w tym artykule, że osobę, która dobrowolnie zaprzestaje działań przewidzianych w tym artykule i która poinformuje o tym fakcie organy państwowe, zwalnia się od odpowiedzialności karnej, o ile te działania nie wiązały się z popełnieniem innego przestępstwa. Zasada ta nie dotyczy osób, które dokonały analogicznych działań w ciągu dwóch lat po dobrowolnym ich zaprzestaniu. Zob. Уголовныий Кодекс Республики Беларусь, 9 июля 1999 г., N 275-3, Национальный Реестр Правовых Актов 1999 г., № 76, 2/50. 
MEN, po czym kierowane były na rok przygotowawczy, który pozwalał no podwyższenie poziomu znajomości języka polskiego tak, aby pozwalał on na kształcenie się na uczelni bez przeszkód. Rok przygotowawczy także dawał gruntowną wiedzę $\mathrm{z}$ historii i kultury Polski, co dawało dobry poziom startu dla studentów podejmujących naukę na polskich uczelniach. Obecnie jednak osoby posiadające Kartę Polaka mają możliwość rozpoczęcia nauki na uczelni bez selekcji poziomu wiedzy, którą zajmowała się Komisja MEN i nie mając przygotowania oferowanego przez stronę polską cudzoziemcom, czyli mając jedynie poświadczoną znajomość języka polskiego na poziomie podstawowym, co w praktyce nieraz oznacza brak możliwości biegłego mówienia i swobodnego porozumiewania się w tym języku, a co za tym idzie - niemożliwość bezproblemowego studiowania. Związane $\mathrm{z}$ tym są także kwestie finansowe w sposób niezwykle ogólny potraktowane przez ustawodawcę w art. 6 ust. 3, w którym mówi się o tym, że posiadacz Karty Polaka zachowuje prawo do ubiegania się o stypendia i inną pomoc przewidzianą dla cudzoziemców, w odrębnych przepisach. Wynika z tego zapisu, że osoba posiadająca Kartę Polaka ma prawo do uzyskania pomocy od państwa jako cudzoziemiec oraz pomocy od uczelni (czyli znowu od państwa) w postaci stypendiów socjalnych, mieszkaniowych, na wyżywienie. Sytuacja ta może zrodzić niechęć wielu studentów polskich, którzy będąc obywatelami Polski nie maja prawa do takiej pomocy ze strony swojego państwa.

Posiadanie Karty Polaka daje także możliwości, których nie posiada każdy obywatel Polski m.in. pozwala na korzystanie ze świadczeń opieki zdrowotnej w stanach nagłych ${ }^{32}$, uprawnia do ulgi $37 \%$ przy przejazdach środkami publicznego transportu zbiorowego kolejowego w pociagach osobowych, pośpiesznych i ekspresowych, na podstawie biletów jednorazowych $^{33}$ oraz umożliwia bezpłatny wstęp do muzeów państwowych. Są

32 Zasady korzystania z pomocy medycznej tego typu określone zostały w ustawie z dnia 27 sierpnia 2004 r. o świadczeniach opieki zdrowotnej finansowanych ze środków publicznych, Dz. U. 2004, Nr 210, poz. 2135, z późn. zm.

33 Zasady określone zostały w ustawie z dnia 20 czerwca 1992 r. o uprawnieniach do ulgowych przejazdów środkami publicznego transportu zbiorowego, Dz. U. 2002, Nr 175, poz. 1440, z późn. zm. Do ulgi w wysokości $37 \%$, zgodnie z Ustawą uprawnieni są: dzieci w wieku powyżej 4 lat do rozpoczęcia nauki w szkole podstawowej; dzieci i młodzież w okresie od rozpoczęcia nauki w szkole podstawowej do ukończenia gimnazjum, szkoły ponadpodstawowej lub ponadgimnazjalnej - publicznej lub niepublicznej o uprawnieniach szkoły publicznej, nie dłużej niż do ukończenia 24 roku życia; studenci do ukończenia 26 roku życia. 
to kwestie warte omówienia, gdyż np. zagwarantowanie opieki zdrowotnej w nagłych wypadkach budzi wątpliwości odnośnie swojej przydatności, gdyż osoby które nie potrzebują wizy przy przekraczaniu granicy z Polską, czyli obywatele Litwy, Łotwy i Estonii podlegają pod ubezpieczenia regulowane na podstawie prawa unijnego. Osoby zaś ubiegające się o wydanie wizy, muszą także obowiązkowo wykupić ubezpieczenie medyczne we własnym kraju, które także gwarantuje opiekę medyczną w nagłych wypadkach. Uprawnienie do ulgi przy korzystaniu z usług PKP także rodzi kolejne pytanie, dlaczego ustawodawca zakłada, że posiadacz Karty Polaka będzie mógł poruszać się na terenie Polski jedynie pociągami, a nie uwzględnia możliwości przyznania ulgi na przejazd autobusami oraz komunikacją miejską. Gdyż osoby, które mają zgodnie z ustawą prawo do $37 \%$ ulgi, mają także ulgi i w tych kategoriach transportu. Zakładając, że możliwość bezpłatnego wstępu do muzeów państwowych ma na celu sprzyjanie poznawaniu kultury polskiej, to pojawia się pytanie dlaczego nie uwzględniono możliwości bezpłatnego albo ulgowego korzystania z kin, teatrów, oper, które stanowią integralną część polskiej kultury.

Zwraca uwagę art. 15, w którym mówi się o uprawnieniach Prezesa Rady Ministrów do określenia wykazu organizacji pozarządowych posiadających osobowość prawną i prowadzących działalność w zakresie pomocy osobom narodowości polskiej zamieszkałym na terenie państw byłego ZSRR, uprawnionych do przyjmowania i przekazywania właściwemu konsulowi wniosków o przyznanie Karty Polaka. Dalej w tym samym artykule mówi się o tym, że w przypadku składania wniosku za pośrednictwem tej organizacji, oceny znajomości języka polskiego dokonuje upoważniony pracownik organizacji, podczas rozmowy z wnioskodawca. Wynikające z tych zapisów wątpliwości dotyczą m.in. trybu określania kompetencji osoby upoważnionej do oceny poziomu znajomości języka polskiego, poza tym może pojawić się sytuacja, kiedy to nie Polska decyduje o tym, kto należy do Narodu Polskiego i ma prawo do korzystania z możliwości, które daje posiadanie Karty Polaka i które są finansowane $\mathrm{z}$ budżetu Polski, tylko organizacje w żaden sposób z tym państwem nie związane i jedyna procedura, która będzie przeprowadzana przez przedstawiciela RP to obecność przy podpisaniu deklaracji przynależności do Narodu Polskiego. Także możliwa jest sytuacja, w której osoba nie mając nic wspólnego ani z Polską, ani nie mająca pochodzenia po uzyskania zaświadczenia od organizacji polonijnej i potwierdzenia od organizacji wyznaczonej przez Prezesa Rady Ministrów znajomości języka polskiego 
będzie mogła uzyskać Kartę i żadnych innych sposobów weryfikacji stosowności przyznania Karty Polaka nie określono. Z tego też powodu istnieje ogromne prawdopodobieństwo korupcji w tej dziedzinie i zaniku obiektywnej oceny kryteriów uprawniających do ubiegania się o przyznanie Karty Polaka.

Ustawa podejmuje problem małoletnich posiadaczy Karty Polaka. Regulacje dotyczące tej kategorii osób zawarto w art. 16, w którym mowa o tym, że Karta przyznawana jest małoletniemu w tym przypadku gdy oboje rodzice posiada Kartę albo jeden z rodziców posiada Kartę i przyznanie Karty małoletniemu odbywa się za zgodą drugiego rodzica. Zaznacza się także art. 16 ust. 2, że po ukończeniu 16 roku życia przyznanie Karty może nastąpić jedynie za zgodą małoletniego. Jednak w krajach byłego ZSRR istnieje zasada, która pozostała jeszcze z ustawodawstwa Związku Radzieckiego, zakładającego, że po uzyskaniu pełnoletniości człowiek ma możliwość zmiany deklarowanej narodowości. Wynika to z tradycji wielonarodowego państwa, jakim był ZSRR, gdzie nie raz rodziny były mieszane pod względem narodowości. Więc może mieć miejsce sytuacja, gdy będąc jeszcze małoletnią osoba otrzymuje Kartę Polaka, po czym po uzyskaniu pełnoletniości zmienia narodowość i korzysta z udogodnień prawnych, które gwarantuje tak państwo obywatelstwa, jak i państwo nowej narodowości. Umożliwiają powstanie takiej sytuacji zapisy zawarte w art. 17, który reguluje okres ważności Karty Polaka oraz tryb przedłużania jej ważności. Dokładnie ustala się 10-letni okres ważności Karty Polaka. Przedłużenie zaś Karty odbywa się po złożeniu wniosku o przedłużenie najpóźniej na 3 miesiące przed terminem upływu ważności Karty, albo najpóźniej na 3 miesiące przed pełnoletniością w przypadku małoletnich. Wyjątek stanowią osoby powyżej 65 roku życia, których Karta Polaka zostaje wydana na czas nieoznaczony. Ponieważ nie wskazane zostały żadne procedury i warunki przedłużenia ważności Karty oprócz złożenia odpowiedniego wniosku, to opisana wyżej sytuacja ze zmianą narodowości jest faktycznie nie do sprawdzenia, gdyż w momencie uzyskania możliwości zmiany narodowości w świetle prawa państwa obywatelstwa omawianej osoby, jest ona pełnoletnia i posiada Kartę ważną przez następne 10 lat.

Karta Polaka weszła w życie w marcu 2008 r. ${ }^{34}$ Ustawa ta, określa uprawnienia osoby, której przyznano Kartę Polaka, zasady przyznawania,

34 Ustawa o Karcie Polaka z dnia 7 września 2007 r., Dz. U. 2007, Nr 180, poz. 1280 z poźn. zm. Ustawą tą zmieniono szereg ustaw, a mianowicie: ustawę z dnia 
które zostaną bardziej szczegółowo omówione niżej, utraty ważności i unieważniania Karty Polaka oraz właściwość i tryb postępowania organów w tych sprawach. Zaznacza się także w Ustawie, że Karta jest dokumentem potwierdzającym przynależność do Narodu Polskiego, jednak nie jest dokumentem uprawniającym do przekraczania granicy ani do osiedlenia się na terytorium Rzeczypospolitej Polskiej, a przyznanie Karty Polaka nie oznacza nabycia polskiego obywatelstwa ani stwierdzenia polskiego pochodzenia w rozumieniu odrębnych przepisów ${ }^{35}$.

Rozpatrując przykład Białorusi, należy stwierdzić, że kwestia wprowadzenia Karty Polaka przez stronę polską została w sposób bardzo niejednoznaczny odebrana przez stronę białoruską - tak polityków, jak i społeczeństwo. Już w lutym 2008 r. politycy białoruscy formułowali zarzuty wobec strony polskiej, podnosząc, że ustawa o Karcie Polaka została uchwalona przez polski Sejm bez jakichkolwiek konsultacji ze stroną białoruską. Na marginesie warto zauważyć, że żądanie tego rodzaju konsultacji godzi w suwerenne prawa Polski, aczkolwiek dobrym zwyczajem byłoby uprzedzenie strony białoruskiej kanałami dyplomatycznymi o szykowanych zmianach. Na tej podstawie zaistniały obawy, że poprzez wprowadzenie Karty Polaka, strona polska będzie próbowała zrobić coś na kształt spisu, a nawet rejestracji, ludności deklarującej pochodzenie polskie w krajach byłego Związku Radzieckiego, żeby móc wykorzystywać to jako sferę swoich wpływów w danych państwach, w pewnym sensie nawet lobby, lub - jak twierdzili niektórzy politycy białoruscy - może doprowadzić do powstania „,piątej kolumny”. Określano to także bardziej łagodnie jako dotknięcie interesów niektórych kategorii obywateli Białorusi, co może destabilizować sytuację etniczną na Białorusi, wywołać napięcie w społeczeństwie białoruskim, zachwiać jego stabilnością i zrodzić brak zaufania między obywatelami Białorusi różnych narodowości ${ }^{36}$.

13 lutego 1984 r. o funkcjach konsulów Rzeczypospolitej Polskiej, ustawę z dnia 7 września 1991 r. o systemie oświaty, ustawę z dnia 20 czerwca 1992 r. o uprawnieniach do ulgowych przejazdów środkami publicznego transportu zbiorowego, ustawę z dnia 20 kwietnia 2004 r. o promocji zatrudnienia i instytucjach rynku pracy, ustawę z dnia 2 lipca 2004 r. o swobodzie działalności gospodarczej, ustawę z dnia 27 sierpnia 2004 r. o świadczeniach opieki zdrowotnej finansowanych ze środków publicznych oraz ustawę z dnia 7 września 2005 r. - Prawo o szkolnictwie wyższym.

35 Art. 1-7 Ustawy o Karcie Polaka.

36 Беларусь предложила ввести мораторий на закон „, Карта поляка”, NewsBY.org - „Новости Беларуси”, http://www.newsby.org/news/2008/02/09/text4101.htm, 26.10.2008. 
A. Łukaszenka wypowiedział się negatywnie na temat Karty, twierdząc, że w ogromnym błędzie są osoby, które uważają, że będą mogły tworzyć swoje prawa na białoruskiej ziemi, wynajdując scenariusze w rodzaju „Karty Polaka” i próbując odgrywać rolę obrońcy mniejszości narodowych. Zaznaczył przy tym, że na Białorusi nie ma mniejszości narodowych, a są tylko obywatele Białorusi ${ }^{37}$. Już pod koniec kwietnia prezydent zmienił swoje podejście do Karty Polaka po konsultacjach ze stroną polską.

Karta Polaka służyć ma nie tylko potwierdzeniu polskiego pochodzenia, ale także ułatwić otrzymanie wizy do Schengen i Polski, gdyż posiadacz Karty Polaka może ubiegać się o zwolnienie z opłaty za przyjęcie i rozpatrzenie wniosku o wydanie wizy pobytowej krajowej lub o refundację tej opłaty. Karta daje także prawo do zwolnienia z obowiązku posiadania zezwolenia na pracę, podejmowania i wykonywania działalności gospodarczej na takich samych zasadach jak obywatele polscy, podejmowania i odbywania studiów, studiów doktoranckich oraz innych form kształcenia, a także uczestniczenia w badaniach naukowych i pracach rozwojowych, korzystania ze świadczeń opieki zdrowotnej w stanach nagłych, ulgi 37\% przy przejazdach środkami publicznego transportu zbiorowego kolejowego w pociagach osobowych, pospiesznych i ekspresowych, na podstawie biletów jednorazowych, bezpłatnego wstępu do muzeów państwowych. Karta daje także jej posiadaczowi pierwszeństwo przy ubieganiu się o pomoc finansową udzielaną osobom fizycznym ze środków budżetu państwa lub budżetów samorządów terytorialnych przeznaczonych na wspieranie Polaków za granicą ${ }^{38}$. Poza tym daje ona pewne korzyści tym, którzy nie wybierają się do Polski. Studenci posiadający Kartę Polaka mają prawo ubiegać się o stypendia rządu polskiego, a także niektórych organizacji pozarządowych, które wspierają rozwój Polonii za granica, jak również - wspierających rozwój kultury i języka polskiego w środowiskach polonijnych ${ }^{39}$. Oczywiście wszystkie te uprawnienia nie rozszerzają się na pozostałe kraje europejskie wchodzące w skład strefy Schengen.

37 Wypowiedź A. Łukaszenki w rosyjskim tygodniku, Izwiestija” przytacza portal informacyjny NewsBY.org, http://www.newsby.org/news/2008/04/30/text7530.htm.

38 Art. 6, ust. 1-2 Ustawy o Karcie Polaka.

39 Польша в связи со скорым присоединением к Шенгенской зоне ввела карту поляка, NewsBY.org - „Новости Беларуси”, http://www.newsby.org/news/2008/ 02/01/text4113.htm, 26.10.2008. 
Procedura uzyskania Karty Polaka okazała się bardziej skomplikowana, niż spodziewały się zainteresowane nią osoby deklarujące polskie pochodzenie. Poza złożeniem wniosku (co biorąc pod uwagę spore zainteresowanie nie jest w cale rzeczą łatwa, nawet po wprowadzeniu uprzedniej rejestracji telefonicznej) wymagane jest wykazanie swojego związku z polskością przez przynajmniej podstawową znajomość języka polskiego, który uważa się za język ojczysty oraz znajomość i kultywowanie polskich tradycji i obyczajów. Zainteresowany musi w obecności konsula Rzeczypospolitej Polskiej złożyć pisemną deklarację przynależności do Narodu Polskiego. Poza tym dla potwierdzenia swojego polskiego pochodzenia powinien on wykazać, że co najmniej jedno z jego rodziców lub dziadków albo dwoje pradziadków było narodowości polskiej lub posiadało obywatelstwo polskie (wymagane są oryginały dokumentów i ich kserokopie $)^{40}$. Dokumentami potwierdzającymi polskie pochodzenie przodków są: polskie dokumenty tożsamości, akty stanu cywilnego lub ich odpisy, metryki chrztu, świadectwa szkolne lub inne dokumenty potwierdzające związek z polskością, dokumenty potwierdzające odbycie służby wojskowej w polskich formacjach wojskowych, dokumenty potwierdzające fakt deportacji lub uwięzienia, zawierające wpis informujący o polskim pochodzeniu, dokumenty o rehabilitacji osoby deportowanej, zawierające wpis informujący o polskim pochodzeniu, zagraniczne dowody tożsamości zawierające informacje na temat narodowości polskiej ich posiadacza, prawomocna decyzja w sprawie stwierdzenia polskiego pochodzenia, wydana zgodnie z przepisami ustawy o repatriacji ${ }^{41}$. W sytuacji, gdy ubiegający się o Kartę Polaka nie może przedłożyć oryginalnych dokumentów dotyczących potwierdzenia swojego pochodzenia polskiego, powinien on przedstawić zaświadczenie upoważnionej organizacji polskiej w Republice Białoruś, potwierdzające aktywne zaangażowanie w działalność na rzecz języka i kultury polskiej lub polskiej mniejszości narodowej przez okres co najmniej ostatnich 3 lat. Tym samym pojawia się tutaj kwestia organizacji kojarzonej z Andżeliką Borys, która została wykreowana przez media polskie na ikonę walki Polaków na Białorusi z reżimem Łukaszenki. Uwaga zamieszczona przez konsulat na swojej stronie internetowej dała powód do podniesienia znaczenia nieformalnego (w oczach władz białoruskich) Związku Polaków na Białorusi i samej A. Borys. Stało się to

$40 \mathrm{Na}$ podstawie informacji zamieszczonych na stronie konsulatu polskiego w Grodnie, http://www.grodnokg.polemb.net/?document=81, 26.10.2008.

41 Art. 13, ust. 3, pkt 1-8, Ustawy o Karcie Polaka. 
jednak powodem waśni wewnątrz społeczności polskiej na Białorusi, która zaczęła spierać się o to, która $z$ organizacji powinna mieć większe uprawnienia do opiniowania wniosków o wydanie Karty Polaka ${ }^{42}$. Wystarczy wspomnieć, że w samym Grodnie są co najmniej 3 grupy mniejszości polskiej, które dość aktywnie konkurują ze sobą, dzieląc społeczność polską w Grodnie na osoby skupione przy jednej z opcji ${ }^{43}$.

Warto także zaznaczyć, że możliwość uzyskania opinii organizacji polonijnej zastępujące potwierdzenie pochodzenia polskiego daje możliwość na uzyskanie Karty Polaka przez osobę o dowolnym pochodzeniu, niekoniecznie deklarującą swoje związki z polskością. Z tej okazji, biorąc pod uwagę niewątpliwe znaczące korzyści finansowe płynące dla mieszkańców regionów przygranicznych, pojawiają się niekiedy pogłoski o przypadkach korupcji przy okazji wydawania wspomnianych opinii. Nie można uważać ich za stuprocentowo pewne, a jedynie za możliwy przejaw wrogich działań ze strony przedstawicieli konkurencyjnych grup polonijnych, uważających, że winny posiadać prawo do wydawania takich opinii.

Zaniepokojenie władz białoruskich budzi także fakt, że osoba ubiegająca się o przyznanie jej Karty Polaka zobowiązana jest do podpisania w obecność konsula generalnego deklaracji o przynależności do Narodu Polskiego. Wzbudziło to także zainteresowanie ze strony KGB, które wzywało do siebie na rozmowy osoby ubiegające się o otrzymanie Karty

42 Tak samo wygląda sytuacja w przypadku opiniowania wniosków o przyznanie przez rząd polski lub polskie organizacje pozarządowe stypendium osobom, które podejmują studia wyższe w Polsce. W tym przypadku znaczenie ma nie tylko przynależność do tej lub inne organizacji polonijnej, ale także kwestia tego do jakiej placówki prowadzącej naukę języka polskiego osoba uczęszczała. Np. przedstawiciele ZPB nie wystawią zaświadczenia osobie, która uczyła się języka w ramach Polskiej Macierzy Szkolnej lub innej organizacji, mimo że członkowie tych organizacji nieraz należą do kilku organizacji polonijnych na raz.

${ }^{43}$ W kwestii mniejszości polskiej na Białorusi por. J. Waszkiewicz, Mniejszość polska w stosunkach polsko-białoruskich, w: Polska - Białoruś..., red. H. Chałupczak, E. Michalik, op. cit., s. 81-89; P. Eberhardt, Przemiany narodowościowe na Białorusi, Editions Spotkania, brw., s. 160-173. Por. także T. Kruczkowski, Uwarunkowania aktywności narodowej Zwiazku Polaków na Białorusi, w: Polska - Biatoruś..., red. H. Chałupczak, E. Michalik, op. cit., s. 103-126; E. Nowicka, Polacy czy cudzoziemcy? Polacy za wschodnia granica, Kraków 2000, s. 15-50. Problem ten porusza także A. Sadowski, Polska polityka wschodnia a pogranicze polsko-biatoruskie, w: Polskie pogranicza a polityka zagraniczna u progu XXI wieku, red. R. Stemplowski, A. Żelazo, Warszawa 2002, s. 281-298. 
Polaka w celu wyjaśnienia czy dana osoba jest świadoma obowiązku podpisania takowej deklaracji, dlaczego chce posiadać Kartę, w jakim celu ma zamiar wyjeżdżać do Polski i jaki ma stosunek do tego kraju. Nieraz zdziwienie mógł budzić system informacji białoruskiego KGB, gdyż placówka dyplomatyczna nie ma obowiązku informowania władz białoruskich odnośnie tego, kto złożył wniosek i kto uzyskał Kartę Polaka, a jednak przedstawiciele KGB kontaktowali się z tymi osobami zawsze w okresie po wyznaczeniu terminu rozmowy z konsulem generalnym RP.

Sporym rozczarowaniem stało się to, że nie wszystkie osoby ubiegające się o Kartę otrzymywały ten dokument. Jak się okazało, przeszkodą okazała się znajomość języka polskiego, gdyż nie wystarczała w tym przypadku znajomość na poziomie pozwalającym prowadzenie handlu przygranicznego i porozumienie się z Polakami. Także niemałą przeszkodą dla uzyskania Karty przez przewoźników okazała się niepisana zasada kolejności wydawania tego dokumentu poszczególnym osobom w rodzinie. Pierwszeństwo do uzyskania Karty mają w praktyce osoby, które ukończyły 70 lat; dalej to prawo przysługuje najstarszej osobie w rodzinie. Jeżeli jakaś osoba deklaruje pochodzenie polskie z racji posiadania takowego pochodzenia przez jego żyjących rodziców, to nie może on ubiegać się, zanim rodzice takiej karty nie uzyskają, nawet jeżeli nie są oni takową Kartą zainteresowani. Przez pierwsze parę miesięcy od uchwalenia ustawy, Karty były wydawane jedynie starszym osobom. Ludzie młodzi, zamierzający podjąć studia wyższe w Polsce mieli problemy z uzyskaniem tego dokumentu i nie otrzymywali go przed rozpoczęciem egzaminów wstępnych. Obecnie trwają zapisy takich osób na rozmowy kwalifikacyjne w sprawie Karty na 2010 r. Powoduje to spore utrudnienia w podjęciu studiów.

Regulacje wprowadzane przez stronę polską dla ułatwienia przekraczania granicy osobom o pochodzeniu polskim poprzez wprowadzenie specjalnych wiz oraz Karty Polaka, wywołało ogromną dyskusję polityczną i społeczną na Białorusi. Władze białoruskie poczuły się w pewnej mierze zagrożone poprzez działania Polski, nie mając pewności co do celów wprowadzenia Karty Polaka. Wynikać to może z utylitarnego podejścia niektórych osób do określenia swojej narodowej przynależności. W tej sytuacji trudno ocenić jak liczna jest mniejszość polska na Białorusi. Władze białoruskie obawiają się wyraźnie, iż Polska wykorzysta Kartę Polaka do mieszania się w wewnętrzne sprawy Białorusi, motywując to ochroną interesów mniejszości polskiej. Negatywnym skutkiem tych wszystkich czynników jest rozłam i wzajemne zwalczanie się organizacji 
polonijnych działających w zachodnich obwodach Białorusi. Bezpośrednim powodem tej sytuacji jest możliwość opiniowania składanych wniosków o Kartę Polaka. Niestety, mimo oczekiwania osób ubiegających o Kartę, uzyskanie tego dokumentu nie ułatwia otrzymania wizy, gdyż wzrósł dość znacząco odsetek odrzucanych wniosków wizowych.

Białorusini są społeczeństwem nie posiadającym świadomości narodowej - albo mającym ją niedostatecznie wykształconą - a zachodnie rejony tego państwa to obszar wielokulturowy ${ }^{44}$. Fakt ten pozwala mieszkańcom tego terenu na zadeklarowanie w razie zaistnienia takowej potrzeby praktycznie dowolnej narodowości. Na tej podstawie można wnioskować, że wydane przez polskie placówki dyplomatyczne Karty Polaka, nie odzwier-

44 B. Białokozowicz, Między wschodem a zachodem. Z dziejów formowania się białoruskiej świadomości narodowej, Białystok 1998, s. 44-87; R. Radzik, Literackie źródła nowoczesnej białoruskości, „Przegląd Powszechny” 1994, nr 3, s. 327; R. Radzik, Między zbiorowościq etnicznq, a wspólnota narodowa, Białorusini na tle przemian narodowych $w$ Europie Środkowo-Wschodniej XIX stulecia, Lublin 2000, s. 139-202; A. Sadowski, Pogranicze polsko-białoruskie. Tożsamość mieszkańców, Białystok 1995, pasim. W kwestii kształtowania tożsamości narodowej zob. instruktywne uwagi K. Warmińskiej, Tatarzy polscy. Tożsamość religijna i etniczna, Kraków 1999, s. 17-54. Szczególnie istotne są wywody odnoszące się do dychotomii między tożsamością narodową a państwową oraz funkcji religii w kształtowaniu się tożsamości etnicznej. Zob. także R. Szwed, Modele tożsamości europejskiej a identyfikacje zbiorowe w Europie, w: Wokół tożsamości: teorie, wymiary, ekspresje, red. I. Borowik, K. Leszczyńska, Kraków 2007, s. 163-178. Jak wskazuje J. Sobczak, jednym z czynników określających tożsamość narodową jest obok języka i religii, literatura piękna a obok niej wspólnota symboli, dziedzictwo kultury, zdolność projektowania przyszłości, możliwość definiowania granic terytorialnych oraz umiejscowienie początku grupy. Białorusini nie ukształtowali wielu z tych elementów, na co złożyły się wypadki historyczne. Język białoruski używany jest przez ludzi wykształconych niechętnie, traktowany jako narzecze ludzi prostych, to że językiem tym posługują się prominentni działacze opozycji odstręcza od niego tych, którzy nie chcieliby być identyfikowani z tą właśnie opcją polityczną. Dziedzictwo kultury wydaje się być niezauważalne, a sprowadza się je do przyśpiewek ludowych i artystycznie opracowanych tańców rzekomo także ludowych. Historia pojmowana jest przez przeciętnych Białorusinów jako nudny zbiór faktów, coraz to inaczej interpretowanych. Punktem odniesienia wydają się być czasy radzieckie pojmowane jako okres dobrobytu i szczęśliwości. Religijność jest dość powierzchowna i nie określa dostatecznie tożsamości narodowej Białorusinów. Ryzykownym wydaje się być stwierdzenie, że Białorusini to prawosławni, gdyż część osób wyznających tę religię czuje się Polakami, a niektórzy Rosjanami. Pamiętać należy o dość znacznej grupie ateistów. Zob. J. Sobczak, Polska tożsamość narodowa w obliczu integracji europejskiej, w: Na obrzeżach polityki, red. M. Kosman, cz. 5, Poznań 2007, s. 100 i n. 
ciedlają ilości osób faktycznie zaliczających się do mniejszości polskiej. Ubieganie się o Kartę Polaka częstokroć wynika z pobudek ekonomicznych, z oceny, że bycie Polakiem się opłaca.

\section{Summary}

The law on the Polish Charter is an element of a certain process, noticeable in Central and Eastern Europe, the purpose of which is to reinforce and retain contacts of respective states with immigrants, that is the members of the nation that predominates in each state who live abroad. The regulations which the Polish side has introduced in order to simplify border crossing for individuals of Polish origin by introducing special visas and the Polish Charter have stirred a profound political and social discussion in Belarus. Belarussian society does not have its own national identity, and is not sufficiently developed. The western part of Belarus is a multicultural region. This allows the dwellers of this region to declare themselves to be of practically any nationality as need arises. It may be concluded then that the Polish Charters, issued by Polish diplomatic posts, do not reflect the number of the actual members of the Polish minority. The applications for a Polish Charter are frequently triggered by economic aspects and the assessment that it pays to be a Pole. 